\title{
Studies on some heavy metals in the River Nile water and fish at Helwan area, Egypt
}

\author{
Abdelhamid ${ }^{1}$, A.M.; Gomaa ${ }^{2}$, A.H. and El-Sayed ${ }^{2}$, H.G.M. \\ 1- Dept. of Anim. Prod., Fac. of Agric., Mansoura Univ., Mansoura, Egypt. \\ 2- Regional Center for Food and Feed, Agric. Res. Cen., Cairo, Egypt.
}

\begin{abstract}
A survy study was carried out in the River Nile at Helwan area to evaluate water parameters and fish quality from three locations during four seasons. Values of water criteria in the tested area were suitable for rearing Nile tilapia fish. All variables (sampling location and season) and their interaction, significantly $(\mathrm{P} \leq 0.05)$ affected the heavy metal levels in the River Nile water. Water Zn level ranged between 0.021 and 0.056, $\mathrm{Cu}$ 0.002-0.049, Pb 0.117-0.176, Cd 0.000-0.000, and Fe 0.038-1.432. Zn, $\mathrm{Cu}$, and $\mathrm{Pb}$ were significantly $\leq(\mathrm{P} .05)$ higher at location No. 2 than the other locations, whereas Fe was significantly $(\mathrm{P} \leq 0.05)$ higher at location No. 1 . This may be attributed to the pollution source, Torah Cement Factory at location No. 1 and Starch and Glucose Factory at location No. 2. Summer season reflected the highest $(\mathrm{P} \leq 0.05)$ levels of $\mathrm{Zn}, \mathrm{Pb}$, and $\mathrm{Fe}$, whereas $\mathrm{Cu}$ level was significantly $(\mathrm{P} \leq 0.05)$ higher in spring. Generally, Cd was absent at all locations and seasons of water sampling. There were no significant $(\mathrm{P} \geq 0.05)$ differences in chemical composition of Nile tilapia fish due to sampling locations; yet, there were significant (\$0.05) differences in $\mathrm{CP}, \mathrm{EE}$, and ash contents due to sampling seasons. In fish muscles, the levels of $\mathrm{Pb}, \mathrm{Cd}$, and $\mathrm{F}$ were significantly $(\mathrm{P} \leq 0.05)$ affected by sampling locations, whereas $\mathrm{Zn}, \mathrm{Cd}, \mathrm{Fe}$, and $\mathrm{F}$ significantly $(\mathrm{P} \leq 0.05)$ affected by sampling seasons. In the whole fish body, the levels of $\mathrm{Zn}, \mathrm{Cu}, \mathrm{Pb}, \mathrm{Fe}$, and $\mathrm{F}$ were significantly (\$D.05) affected by sampling locations and seasons. Fish muscles bioacumulated higher $\mathrm{Pb}$ than $\mathrm{Cu}, \mathrm{Fe}$, and $\mathrm{Zn}$, respectively. The Fe accumulation was highest in the whole fish body followed by $\mathrm{Zn}, \mathrm{Cu}$ and $\mathrm{Pb}$, respectively. It was clear that each of $\mathrm{Zn}, \mathrm{Cu}$, and Fe were more bioaccumulated in the whole fish body than in the fish muscles. This may depend on the target organ for each element where it deposits. There were significantly positive correlations between $\mathrm{Pb} / \mathrm{Cu}$ and $\mathrm{Pb} / \mathrm{Cd}$ in fish muscles, whole fish $\mathrm{Zn} /$ muscular $\mathrm{Fe}, \mathrm{Cd} / \mathrm{Cu}, \mathrm{Cu} / \mathrm{Fe}$ as well as $\mathrm{Cd} / \mathrm{Pb}$ in whole fish, whole fish $\mathrm{Fe}$ /muscular $\mathrm{Fe}$, water $\mathrm{Zn} /$ muscular $\mathrm{Cd}$, water $\mathrm{Cu} /$ muscular $\mathrm{Cu}, \mathrm{Cu} / \mathrm{Zn}$ in water, water $\mathrm{Fe} /$ muscular $\mathrm{Fe}$, water $\mathrm{Fe} /$ whole fish $\mathrm{Cu}$, water $\mathrm{Fe} /$ whole fish $\mathrm{Fe}$, and $\mathrm{Fe} / \mathrm{Pb}$ in water. Also, there were significantly negative correlations between water $\mathrm{Cu} /$ whole fish $\mathrm{Pb}$ and water $\mathrm{Fe} /$ muscular $\mathrm{Cu}$. So, residues of some heavy metals in fish are affected by the presence of some industries nearby the River Nile that may negatively affect human health of the fish consumer from such contaminated water. Therefore, it is a must to manage such factories to be environmentally consonant by treating its wastes before exposure to the environment.
\end{abstract}

Keywords: Helwan, River Nile, Nile tilapia, Water, Heavy metals.

\section{ITRODUCTION}

Fish react to stress in different ways, depending on the severity and length of exposure to the stressor. Fish may die almost immediately from shock if the stressor is sufficiently severe or, at the other extreme they may adapt to a mild or slow developing stressor and suffer no long-term effects. Fish may also respond to a 
stressor by altering their physiology to the point that natural resistance and immunity to disease is reduced and they become more susceptible to infectious diseases (Wedemeyer, 1997). In ectothermic or poikilothermic animals like fish, environmental changes can have significant effects on the immune system. Seasonal and diurnal changes in immune response and disease prevalence have been reported in wild fish; these factors being changes in temperature and light density (Bowden 2008). Transition of metal elements depends on the distribution of these elements between the dissolved form and molecular shape, as well as on other environmental conditions. Minerals in water bodies are controlled by the physical and chemical equilibrium. The hydro-biogeochemical cycle amend the forms and the presence of these items (Fang et al., 2002). Therefore, the aim of the present study was to survey the water status in Helwan area (as a polluted area) comparing with a control one (far from industrial factories) from the view point of physico-chemical properties as well as five heavy metals (lead, $\mathrm{Pb}$; cadmium, $\mathrm{Cd}$; cupper, $\mathrm{Cu}$; zinc, $\mathrm{Zn}$ and iron, $\mathrm{Fe}$ ), besides the levels of these five heavy metals (plus flourine, $\mathrm{F}$ ) in the most commercial and consumed fish species in Egypt (Nile tilapia, Oreochromis niloticus).

\section{MATERIALS AND METHODS}

This study was carried out throughout the four seasons of year 2012 at three stations of the industrial drainage contaminated locations in the River Nile at a part of Great Cairo (Cairo/Giza governorates).

\section{Locations of the collected samples:}

Three locations were determined for samples collection; namely location No. 1 is Torah Cement Factory area at Helwan, location No. 2 is Starch and Glucose Factory area, and location No. 3 is Zamalek and Empapa areas. The distance between locations No. 1 and 2 was ca. $1 \mathrm{~km}$, whereas between these and the $3^{\text {rd }}$ one (Zamalek and Empapa areas, as a control area free from the industrial activities and wastes) was ca. $20 \mathrm{Km}$.

\section{Collected samples:}

Water and fish (Nile tilapia, Oreochromis niloticus) samples were collected from the previously mentioned locations during the $1^{\text {st }}$ season (winter, 16-18 February 2012 from locations No. 1, 2, and 3, respectively), $2^{\text {nd }}$ season (spring, 4-6 May for the three locations, respectively), $3^{\text {rd }}$ season (summer, 31/7, 3/8, and $2 / 8$, from the three locations, respectively), and $4^{\text {th }}$ season (autumn, 14, 15, and 18/10/2012, from the three locations, respectively). Fish samples (each of 20 fish, 10 for muscles analysis and the other 10 for the whole body analysis, each 10 fish were considered as a collective sample to be analyzed in triplicates) were caught by fisherman's net, and water samples were collected in 2- liter clean bottles from a 2-meter depth of the River Nile using a 2-meter wooden raw fitted to 2 bottles to be complete filled with water (without any air bubbles) from this depth.

\section{Samples preservation:}

After catching the fish samples, fish were kept in plastic bags, tied well, transported directly to the laboratory and kept frozen in a deep freezer at- $20^{\circ} \mathrm{C}$. Whereas water samples in the collecting bottles were kept directly in a refrigerator at $+4{ }^{\circ} \mathrm{C}$.

\section{Tested parameters:}

Fish weight and total length were recorded individually for the nearest one gram and centimeter, respectively according to Abdelhamid (1996) for all fish. Two water samples collected from each location and season were analyzed physico-chemically 
besides the analyses for the heavy metals ( $\mathrm{Pb}, \mathrm{Cd}, \mathrm{Zn}, \mathrm{Cu}$, and $\mathrm{Fe}$ ). About 20 fish were caught from each location and season, weight and total length for each fish were recorded, and then fish were sub-divided into 2 parts, one for filleting for the flesh (muscles) analysis (proximate analysis for dry matter, crude protein, ether extract, and ash) and heavy metals ( $\mathrm{Pb}, \mathrm{Cd}, \mathrm{Zn}, \mathrm{Cu}, \mathrm{Fe}$, and $\mathrm{F}$ ), and the other was analyzed as a whole (fish carcass) for the muscles. All tested parameters were carried out at the Regional Center for Food and Feed, Agricultural Research Center. Chemical analysis of fish samples from different sampling locations and seasons was carried out according to AOAC (1995).

Analyses of physico-chemical parameters of water were carried out according to Abdelhamid (1996) including color, odor, specific gravity, pH (Orion 710A, U.S.A), conductance, salinity (Thermo Electron Corporation, U.S.A), turbidity (Turbidimeter, Orbco Hellinge, U.S.A), hardness, carbonate $\left(\mathrm{CO}_{3}\right)$, bicarbonate $\left(\mathrm{HCO}_{3}\right)$, dissolved oxygen (DO), sulphate (SO4) (T80 UV/VIS Spectpometercc, PG Instruments Ltd), total solids (T.S), total dissolved solids (T.D.S), and total suspended solids (T.S.S) (Oven, Heraeus Instruments, German). The analyses of heavy metals ( $\mathrm{Pb}, \mathrm{Cd}, \mathrm{Zn}$, $\mathrm{Cu}, \mathrm{Fe}$, and $\mathrm{F}$ ) in water (without digestion, and no F) and fish samples (after digestion) were carried out according to AOAC (2006), using Atomic Absorption spectrometer (ZEE nit 700P, Analytic Jena, Germany) with lamps' wave lengths 283.3 for $\mathrm{Pb}, 228.8$ for $\mathrm{Cd}, 213.9$ for $\mathrm{Zn}, 324.8$ for $\mathrm{Cu}$, and 248.3 for Fe, equipped with MHS-10 hydride generation system. $\mathrm{Fe}, \mathrm{Cu}, \mathrm{Cd}, \mathrm{Pb}$ and $\mathrm{Zn}$ irons were analyzed using a gas mixture of $\mathrm{C}_{2} \mathrm{H}_{2}$ / air (flow rate of $50 \mathrm{nl} / \mathrm{h}$ for $\mathrm{Cd}, \mathrm{Cu}$, and $\mathrm{Zn}$ and $65 \mathrm{nl} /$ $\mathrm{h}$ for $\mathrm{Pb}$ and $\mathrm{Fe}$ ) flame atomic absorption spectrophotometer (and spectrophotometrically for the flourine in fish samples, using ATi Orion 940). The burner height was $8 \mathrm{~cm}$, fuel flow 30, oxidant flow 60, and slide width $0.7 \mathrm{~nm}$. Blank samples from the used chemicals as well as specked samples (internal standards) were undertaken to correct the obtained data.

Statistical Analysis:

Using S.A.S. (2001) and Duncan (1955), numerical data collected were statistically analyzed for analysis of variance and least significant difference as well as Pearson correlation.

\section{RESULTS AND DISCUSSION}

\section{Water analyses: \\ Physical parameters:}

Table 1 presents some physical parameters measured in the River Nile water from the three tested locationd throughout the four seasons. All tested samples were colorless and odorless. The specific gravity ranged between 0.9622 (at location No. 1 in spring and location No. 3 in summer) and 1.0025 (at location No. 1 in summer) $\mathrm{g} / \mathrm{ml}$ at $30{ }^{\circ} \mathbf{C}$. The $\mathrm{pH}$ values were in the range $6.8-8.8$ at the $1^{\text {st }}$ location during spring and autumn, respectively. Conductivity (m hos/cm) was lowest (17) at location No. 2 during spring and highest (332) at location No. 3 during winter. Salinity ranged between 0.01 and $10.0 \%$ at location No. 3 during autumn and location No. 2 during winter, respectively. 
Table 1: Overall mean of some physical parameters of the River Nile water as affected by different sampling locations and seasons.

\begin{tabular}{|c|c|c|c|}
\hline \multirow[t]{2}{*}{ Seasons } & \multicolumn{3}{|c|}{ Locations No. } \\
\hline & 1 & 2 & 3 \\
\hline \multicolumn{4}{|c|}{ Color } \\
\hline Winter & Colorless & Colorless & Colorless \\
\hline Spring & Colorless & Colorless & Colorless \\
\hline Summer & Colorless & Colorless & Colorless \\
\hline Autumn & Colorless & Colorless & Colorless \\
\hline \multicolumn{4}{|c|}{ Odor } \\
\hline Winter & Odorless & Odorless & Odorless \\
\hline Spring & Odorless & Odorless & Odorless \\
\hline Summer & Odorless & Odorless & Odorless \\
\hline Autumn & Odorless & Odorless & Odorless \\
\hline \multicolumn{4}{|c|}{ Specific gravity, $\mathrm{g} / \mathrm{ml}$ at $30^{\circ} \mathrm{C}$} \\
\hline Winter & 0.9930 & 0.9990 & 0.9782 \\
\hline Spring & 0.9622 & 0.9991 & 0.9982 \\
\hline Summer & 1.0025 & 0.9948 & 0.9622 \\
\hline Autumn & 0.9762 & 0.9948 & 0.9966 \\
\hline \multicolumn{4}{|c|}{$\mathrm{pH}$} \\
\hline Winter & 7.6 & 7.3 & 7.3 \\
\hline Spring & 6.8 & 7.0 & 7.2 \\
\hline Summer & 7.4 & 7.3 & 7.7 \\
\hline Autumn & 8.0 & 7.3 & 7.5 \\
\hline \multicolumn{4}{|c|}{ Conductivity, $\mathrm{m}$ hos/cm } \\
\hline Winter & 297.2 & 294.1 & 332.0 \\
\hline Spring & 254.4 & 17.06 & 273.6 \\
\hline Summer & 225.0 & 224.9 & 223.0 \\
\hline Autumn & 273.9 & 224.9 & 271.7 \\
\hline \multicolumn{4}{|c|}{ Salinity, \%о } \\
\hline Winter & 0.1 & 0.1 & 0.2 \\
\hline Spring & 0.1 & 10 & 0.1 \\
\hline Summer & 0.1 & 0.1 & 0.1 \\
\hline Autumn & 0.1 & 0.1 & 0.01 \\
\hline \multicolumn{4}{|c|}{ Turbidity, NTU } \\
\hline Winter & 0.4 & 0.4 & 1 \\
\hline Spring & 0.5 & 0.1 & 6 \\
\hline Summer & 0.7 & 0.4 & 5 \\
\hline Autumn & 0.5 & 0.4 & 3 \\
\hline
\end{tabular}

Turbidity (NTU) was lowest (0.1) at location No. 2 in spring and location No. 3 in winter, but the highest (0.7) was at location No. 1 in summer. These variable results are due to location and season, particularly at the industrial locations No. 1 and 2 in summer (for the presence of pollutants from Helwan Torah Cement Factory and Starch and Glucose Factory, comparing with the non industrial location No. 3 as a control area). However, water color is depending on water depth and its planktonic content and salinity, and the color of the surrounding subjects. Water specific gravity is depending on salinity and depth of water (positively) and water temperature (negatively). Water conductivity and salinity are depending on the salts concentration in the water. Turbidity is depending on water content of plankton, floods, rains, fish habits and activity (Abdelhamid, 1994 and 2009a).

\section{Chemical parameters:}

Table 2 shows the mean values (mg/l) of some chemical parameters measured in the River Nile water throughout the four seasons from different locations. These values ranged between 128-3954 for hardness, 0-210 alkalinity, 2.7-9.4 nitrate, 0-9 carbonate, 68-265 bicarbonate, 4.34-7.14 dissolved oxygen, 1.28-902 sulphate, 13318520 total solids, 52-15404 total dissolved solids, and 4-3116 for total suspended solids. However, hardness is a measurement of calcium and magnesium ions; 
whereas, alkalinity is a measurement of carbonate and bicarbonate or the buffering capacity. Dissolved oxygen is depending on the highest from sea surface; water temperature, salinity, and depth; respiration of all organisms and time of day and night. The $\mathrm{pH}$ is depending on the presence of plants consuming of $\mathrm{CO}_{2}$, presence of nitrogen pollution sources and sedimentation acidity (Abdelhamid, 1994 and 2009a). These ranges of water criteria are suitable for rearing Nile tilapia fish according to Abdelhamid (1994, 1996, 2009a \& b) and Abdelhakeem et al. (2002).

Table 2: Overall mean (mg/l) of some chemical parameters of the River Nile water as affected by different sampling locations and seasons.

\begin{tabular}{|c|c|c|c|c|c|c|c|c|c|c|}
\hline Treat. & Hard. & Alka. & $\mathrm{NO}_{3}$ & $\mathrm{CO}_{3}$ & $\mathrm{HCO}_{3}$ & DO & $\mathrm{SO}_{4}$ & T.S & T.D.S & T.S.S \\
\hline $1 \times W$ & 140 & 150 & 4.9 & 9 & 166 & 4.60 & 3.98 & 240 & 212 & 28 \\
\hline 1xSp & 128 & 210 & 4.5 & 0 & 265 & 4.93 & 91.2 & 260 & 240 & 20 \\
\hline 1xSu & 137 & 0 & 2.7 & 0 & 159 & 7.14 & 30.5 & 176 & 116 & 60 \\
\hline $1 \times \mathbf{x A}$ & 137 & 160 & 4.3 & 0 & 189 & 6.06 & 34.4 & 272 & 240 & 32 \\
\hline $2 \times W$ & 140 & 150 & 9.4 & 9 & 99 & 4.91 & 1.28 & 368 & 52 & 316 \\
\hline 2xSp & 3954 & 0 & 5.7 & 9 & 168 & 5.45 & 902 & 18520 & 15404 & 3116 \\
\hline $2 \mathrm{xSu}$ & 133 & 0 & 4.7 & 0 & 156 & 6.58 & 31.5 & 168 & 128 & 40 \\
\hline $2 \mathrm{xA}$ & 141 & 192 & 4.8 & 6 & 180 & 5.17 & 36.8 & 280 & 134 & 4 \\
\hline $3 \times W$ & 136 & 146 & 5.1 & 6 & 68 & 5.17 & 1.73 & 256 & 72 & 184 \\
\hline $3 x S p$ & 136 & 146 & 3.3 & 6 & 68 & 5.17 & 27.0 & 256 & 184 & 72 \\
\hline $3 x S u$ & 129 & 0 & 5.7 & 3 & 153 & 4.60 & 24.0 & 184 & 112 & 72 \\
\hline $3 \mathbf{X A}$ & 150 & 146 & 5.5 & 6 & 186 & 4.34 & 35.6 & 133 & 260 & 20 \\
\hline
\end{tabular}

\section{Heavy metals:}

Table 3 illustrates the effect of season and location (as well as their interaction) of water sampling from the River Nile on the level (ppm or $\mathrm{mg} / \mathrm{l}$ ) of some heavy metals. All variables and their interaction, significantly $(\mathrm{P} \leq 0.05)$ affected these parameters. Water $\mathrm{Zn}$ level ranged between 0.021 and $0.056, \mathrm{Cu} 0.002-0.049, \mathrm{~Pb}$ 0.117-0.176, Cd 0.000-0.000, and Fe 0.038-1.432. Zn, $\mathrm{Cu}$, and $\mathrm{Pb}$ were significantly $(\mathrm{P} \geq 0.05)$ higher at location No. 2 than the other locations, whereas Fe was significantly $(\mathrm{P} \geq 0.05)$ higher at location No. 1 . This may be attributed to the pollution source, Torah Cement Factory at location No. 1 and Starch and Glucose Factory at location No. 2. Summer season reflected the highest $(\mathrm{P} \geq 0.05)$ levels of $\mathrm{Zn}, \mathrm{Pb}$, and $\mathrm{Fe}$, whereas $\mathrm{Cu}$ level was significantly ( $\mathrm{P} 0.05)$ higher in spring. Generally, Cd was absent at all locations and seasons of water sampling. From the interaction analysis, Zn was highest $(0.090 \mathrm{ppm})$ at location No. 2 in summer, $\mathrm{Cu}(0.049 \mathrm{ppm})$ at location No. 1 in spring, $\mathrm{Pb}(0.178 \mathrm{ppm})$ at location No. 3 in spring, and Fe (1.432 ppm) at location No. 1 in summer. From the obtained data, all water samples from different locations and seasons contained higher levels than the refusable limit of $\mathrm{Pb}$ according to the following American Public Service limitations. The American Public Service limitations in the drinking water included the following parameters in $\mathrm{mg} / \mathrm{l}$ (cited by Abdelhamid, 1996):

$\begin{array}{lll}\text { Measurement } & \text { Maximum tolerance limit } & \text { Refusable limit } \\ \mathrm{Cd} & - & 1.0 \\ \mathrm{Cu} & 1.0 & - \\ \mathrm{Fe} & 0.3 & - \\ \mathrm{Pb} & - & 0.05\end{array}$


Table 3: Overall mean (mg/l), standard error, and probability level of different heavy metals concentration of the River Nile water as affected by different sampling locations and seasons and their interaction.

\begin{tabular}{|c|c|c|c|c|c|}
\hline Treat. & Zn & $\mathbf{C u}$ & $\mathbf{P b}$ & Cd & $\mathbf{F e}$ \\
\hline \multicolumn{6}{|l|}{ Location } \\
\hline 1 & $0.034^{\mathbf{b}}$ & $0.019^{\mathbf{b}}$ & $0.145^{b}$ & 0.000 & $0.564^{\mathrm{a}}$ \\
\hline 2 & $0.045^{\mathrm{a}}$ & $0.022^{\mathrm{a}}$ & $0.152^{\mathrm{a}}$ & 0.000 & $0.231^{\mathrm{b}}$ \\
\hline 3 & $0.030^{\mathbf{b}}$ & $0.008^{\mathrm{C}}$ & $0.147^{\mathbf{b}}$ & 0.000 & $0.246^{6}$ \\
\hline$\pm \mathrm{SE}$ & 0.001 & 0.0006 & 0.001 & 0.000 & 0.133 \\
\hline P-value & 0.0001 & 0.0001 & 0.015 & 0.000 & 0.0001 \\
\hline \multicolumn{6}{|l|}{ Season } \\
\hline Winter & $0.033^{c}$ & $0.016^{\mathbf{c}}$ & $0.124^{\mathrm{d}}$ & 0.000 & $0.127^{\mathrm{d}}$ \\
\hline Spring & $0.040^{\mathbf{b}}$ & $0.024^{\mathrm{a}}$ & $0.156^{\mathbf{b}}$ & 0.000 & $0.405^{b}$ \\
\hline Summer & $0.049^{\mathrm{a}}$ & $0.020^{\mathbf{b}}$ & $0.165^{\mathrm{a}}$ & 0.000 & $0.649^{\mathrm{a}}$ \\
\hline Autumn & $0.023^{d}$ & $0.005^{d}$ & $0.146^{\mathrm{c}}$ & 0.000 & $0.208^{\mathrm{C}}$ \\
\hline$\pm \mathrm{SE}$ & 0.002 & 0.0007 & 0.001 & 0.000 & 0.015 \\
\hline P-value & 0.0001 & 0.0001 & 0.0001 & 0.000 & 0.0001 \\
\hline \multicolumn{6}{|c|}{ Location x Season } \\
\hline $1 \times W$ & 0.029 & 0.014 & 0.129 & 0.000 & 0.218 \\
\hline 1xSp & 0.056 & 0.049 & 0.124 & 0.000 & 0.092 \\
\hline $1 x S u$ & 0.030 & 0.011 & 0.176 & 0.000 & 1.432 \\
\hline $1 \mathbf{x A}$ & 0.021 & 0.002 & 0.151 & 0.000 & 0.514 \\
\hline $2 x W$ & 0.038 & 0.022 & 0.127 & 0.000 & 0.101 \\
\hline 2xSp & 0.028 & 0.016 & 0.168 & 0.000 & 0.283 \\
\hline $2 x S u$ & 0.090 & 0.041 & 0.164 & 0.000 & 0.470 \\
\hline $2 \times A$ & 0.024 & 0.010 & 0.149 & 0.000 & 0.071 \\
\hline $3 x W$ & 0.030 & 0.011 & 0.117 & 0.000 & 0.061 \\
\hline 3xSp & 0.037 & 0.008 & 0.178 & 0.000 & 0.841 \\
\hline $3 x S u$ & 0.027 & 0.007 & 0.154 & 0.000 & 0.044 \\
\hline $3 \mathbf{x A}$ & 0.024 & 0.004 & 0.137 & 0.000 & 0.038 \\
\hline$\pm \mathrm{SE}$ & 0.003 & 0.001 & 0.003 & 0.000 & 0.026 \\
\hline P-value & 0.0001 & 0.0001 & 0.0001 & 0.0001 & 0.0001 \\
\hline
\end{tabular}

Also, according to the following items of low No. 48 year 1982, the alkalinity at 7 locations from the 12 locations was not suitable. All water samples contained higher $\mathrm{NO}_{3}$ and $\mathrm{Pb}$ levels than these permissible levels. TSS was not suitable at location No. 2 in spring as well as Fe at location No. 1 in summer. The Egyptian water low No. 48/1982 for the freshwater surfaces included the following parameters in $\mathrm{mg} / \mathrm{l}$ (cited by Abdelhamid, 1996):

$\begin{array}{ll}\text { Measurement } & \text { Load } \\ \text { Alkalinity } & 20-150 \\ \mathrm{Cd} & \text { Not more than } 0.01 \\ \mathrm{Cu} & \text { Not more than } 1.0 \\ \mathrm{DO} & \text { Not less than } 5 \\ \mathrm{Fe} & \text { Not more than } 1.0 \\ \mathrm{NH}_{3} & \text { Not more than } 0.5 \\ \mathrm{NO}_{3} & \text { Not more than } 45 \\ \mathrm{~Pb} & \text { Not more than } 0.05 \\ \mathrm{pH} & 7.0-8.5 \\ \mathrm{SO}_{4} & \text { Not more than } 200 \\ \mathrm{TSS} & 500 \\ \text { Turbidity } & 50 \text { NTU } \\ \text { Zn } & \text { Not more than } 1.0\end{array}$

However, the suitable water conditions for fish breeding are 50-300 ppm hardness, 50-200 ppm alkalinity, not more than 0.05 ppm NO${ }_{3}$, not more than 0.4-1.2 
ppm $\mathrm{Cd}$, not more than $0.01 \mathrm{ppm} \mathrm{Cu}$, not more than $1.0 \mathrm{ppm} \mathrm{Fe}$, not more than 0.1 ppm Pb, not more than $0.01 \mathrm{ppm} \mathrm{Zn}, 5 \mathrm{ppm}$ DO at least, and 4.5-10 pH (Abdelhamid, 1994 and 2009a) or $20 \mathrm{ppm}$ at least alkalinity, 6.7-8.6 pH, less than $400 \mathrm{ppm}$ TDS, less than $80 \mathrm{ppm}$ TSS, less than $0.02 \mathrm{ppm} \mathrm{NH}_{3}, 0.0005-0.005 \mathrm{ppm} \mathrm{Cd}, 0.006-0.03$ ppm $\mathrm{Cu}$, not less than $5 \mathrm{ppm} \mathrm{DO}$, less than $0.1 \mathrm{ppm} \mathrm{Fe}$, less than $0.02 \mathrm{ppm} \mathrm{Pb}$, less than $1.0 \mathrm{ppm} \mathrm{NO}_{3}$, less than $1.0 \mathrm{ppm} \mathrm{NO}$, less than 5\%o salinity, less than $50 \mathrm{ppm}$ $\mathrm{SO}_{4}$, and less than 0.005 ppm Zn (UDEPA, 1979-1980, cited by Abdelhakeem et al., 2002). Abdelhakeem et al. (2002) classified the fluorine as not critical element; whereas $\mathrm{Cu}, \mathrm{Cd}, \mathrm{Pb}$ and $\mathrm{Zn}$ as very toxic elements. So, they gave the following permissible levels in ppm for water:

$\begin{array}{ll}\text { Element } & \text { Tolerance limit in water } \\ \mathrm{Cd} & 0.01 \\ \mathrm{Cu} & 1.00 \\ \mathrm{Fe} & 0.35 \\ \mathrm{~Pb} & 0.10 \\ \mathrm{Zn} & 5.00\end{array}$

Generally, the laboratories of Egyptian Ministry of Health analyzed water samples from the River Nile during 2012 (from January till December) from great Cairo governorates including water inlets of Giza, Empapa, Roda, Ma'ady, Badrasheen, Gold Island; Starch and Glucose Factory, Tepen 1, Tepen 2 and Hawamdeia for heavy metals. They obtained the following ranges in ppm: 0.0002$0.0048 \mathrm{Cd}, 0.001-0.180 \mathrm{Cu}, 0.001-0.022 \mathrm{~Pb}$, and 0.001-0.115 Zn. That means that the obtained results in the present study are in accordance with the above mentioned analyses of the Egyptian Ministry of Health concerning $\mathrm{Cu}$ and $\mathrm{Zn}$, but disagree concerning $\mathrm{Pb}$ levels since the present study gave higher levels (0.117-0.176 ppm). However, $\mathrm{Pb}$ content was significantly higher in water in winter than in summer (Abdelhamid and El-Ayouty, 1989). Lead causes hemorrhages and congestion of the gastrointestinal tract and kidneys of fish (Abdelhamid and El-Ayouty, 1991). The no effect level of $\mathrm{Cd}, \mathrm{Pb}$ and $\mathrm{Fe}$ in water for growing aquatic life are 0.03, 0.10 and 1.00 ppm, respectively (Yokokawa, 2000). Comparing these standards with the levels obtained herein, it would be indicated that there is water pollution with $\mathrm{Pb}$ in all tested locations and seasons.

$\mathrm{Cd}$ in water is negatively affect fish growth, feed and vitamin $\mathrm{C}$ utilization. Fe also is toxic for fish, since it damages fish gills and their function. $\mathrm{Pb}$ reduces hemoglobin content and red blood cells count of fish (Abdelhamid, 2003). However, any degree of poisoning will weaken the fish, making it vulnerable towards diseases. Heavy metals can create problems and be concentrated in waterway organisms up to 9100 times more than the surrounding environment's levels, so may lead to acute or chronic effects (WRC, 2005).

However, Hovanec (1998) mentioned that metals are involved in many aspects of fish keeping and aquarium water metals are acutely toxic while others are necessary for the life of the fish nitrifying bacteria. Still others are responsible for such basic water hardness. For a metal to be toxic, it almost always has ionized or free form. Water hardness can have a drastic effect on metal toxicity. Since the toxicity and biological activity of many metals and metalloids is profoundly influenced by their chemical form. The metabolism of ingested metals could significantly modify their toxicity. The micro-organisms in lakes, rivers and soil could biotransform metallic compounds (Rowland, 1981).

Moreover, Radwan (2000) reported average values of dissolved heavy metals (Cd, Fe and $\mathrm{Pb}$ ) in Lake Burullos water as 1.93, 2.46 and $2.67 \mathrm{mg} / \mathrm{l}$, respectively. He added that, levels of heavy metals are correlated with salinity changes due to the 
discharge of water. However, heavy metal contamination of water is one of the environmental stressors affecting significantly and negatively lysozyme activity of fish serum, intestinal scrapping and skin mucus as well as serum hemolytic activity, leukocytes count, packed cell volume, hemoglobin concentration, plasma protein and glucose concentrations (Abdelhamid et al., 2006a).

Also, Abdelhamid et al (2013) studied the effects of both collection seasons and collection stations of the fish rearing water as well as their interaction on some heavy metals ( $\mathrm{Pb}, \mathrm{Cd}, \mathrm{Cu}, \mathrm{Zn}$ and $\mathrm{Fe})$. It reflects their significant $(\mathrm{P} \leq 0.0001)$ effects on these elements' contents in the water. The highest $\mathrm{Pb}$ and $\mathrm{Cd}$ values, being 1.0 and $1.4 \mathrm{ppm}$, respectively, $\mathrm{Cu} 0.160 \mathrm{ppm}, \mathrm{Zn} 3.200 \mathrm{ppm}$ and Fe $0.300 \mathrm{ppm}$. Generally, these studied elements took the following descending order: $\mathrm{Z} \geq \mathrm{Cd} \geq \mathrm{Pb} \geq \mathrm{Fe} \geq \mathrm{Cu}$ in water.

\section{Fish analyses: \\ Fish growth:}

Table 4 presents overall mean, standard error of means, and probability level of live body weight, total body length, and condition (K) factor of Nile tilapia fish as affected by different sampling locations and seasons and their interaction. All variables and their interaction significantly $(\mathrm{P} \leq 0.05)$ affected these parameters. Location No, 1 has the best fish weight and total length, but location No. 3 reflected the highest K-factor. Autumn samples gave the best fish weight and total length, but spring fish samples reflected the highest K-factor. However, from the interaction, it is clear that the best fish weight and total length was in location No. 1 in autumn, whereas the highest K-factor was calculated for fish from location No. 3 in spring.

Table 4: Overall mean, standard error, and probability level of live body weight, total body length, and condition (K) factor of Nile tilapia fish as affected by different sampling locations and seasons and their interaction.

\begin{tabular}{|c|c|c|c|}
\hline Treat. & Weight (g) & Length $(\mathrm{cm})$ & K-factor \\
\hline \multicolumn{4}{|l|}{ Location } \\
\hline 1 & $92.170^{\mathrm{a}}$ & $18.013^{\mathrm{a}}$ & $1.549^{b}$ \\
\hline 2 & $70.164^{b}$ & $16.251^{b}$ & $1.603^{\mathrm{ab}}$ \\
\hline 3 & $74.846^{b}$ & $16.330^{\mathbf{b}}$ & $1.671^{\mathrm{a}}$ \\
\hline$\pm \mathrm{SE}$ & 3.164 & 0.227 & 0.030 \\
\hline P-value & 0.0001 & 0.0001 & 0.020 \\
\hline \multicolumn{4}{|l|}{ Season } \\
\hline Winter & $70.26^{\mathrm{c}}$ & $17.35^{b}$ & $1.38^{\mathrm{c}}$ \\
\hline Spring & $82.93^{b}$ & $16.29^{c}$ & $1.86^{\mathrm{a}}$ \\
\hline Summer & $57.04^{\mathrm{d}}$ & $15.33^{\mathrm{d}}$ & $1.56^{\mathrm{b}}$ \\
\hline Autumn & $105.98^{\mathrm{a}}$ & $18.47^{\mathrm{a}}$ & $1.61^{\mathbf{b}}$ \\
\hline$\pm \mathrm{SE}$ & 3.654 & 0.263 & 0.0353 \\
\hline P-value & 0.0001 & 0.0001 & 0.0001 \\
\hline \multicolumn{4}{|c|}{ Location x Season } \\
\hline $1 \times W$ & 72.925 & 18.810 & 1.137 \\
\hline 1xSp & 102.123 & 17.640 & 1.852 \\
\hline 1xSu & 61.610 & 15.750 & 1.556 \\
\hline 1xA & 132.020 & 19.850 & 1.650 \\
\hline $2 \times W$ & 70.832 & 17.050 & 1.457 \\
\hline $2 x S p$ & 67.763 & 15.330 & 1.821 \\
\hline $2 \times S u$ & 61.050 & 15.575 & 1.597 \\
\hline $2 \times A$ & 81.010 & 17.050 & 1.538 \\
\hline $3 \times W$ & 67.052 & 16.190 & 1.574 \\
\hline $3 x S p$ & 78.931 & 15.920 & 1.910 \\
\hline $3 x S u$ & 48.470 & 14.680 & 1.530 \\
\hline $3 \times A$ & 104.930 & 18.530 & 1.670 \\
\hline$\pm \mathrm{SE}$ & 6.328 & 0.455 & 0.0611 \\
\hline P-value & 0.0011 & 0.026 & 0.0013 \\
\hline
\end{tabular}




\section{Composition of Fish:}

\section{Muscular composition:}

Table 5 presents chemical composition of tilapia muscles collected from the tested fish as affected by sampling locations and seasons as well as their interaction. There were no significant $\underset{(\mathbb{P} .05)}{ }$ differences in chemical composition due to sampling locations; yet, there were significant (\$0.05) differences in $\mathrm{CP}, \mathrm{EE}$, and ash contents due to sampling seasons. Since winter samples reflected higher CP and EE percentages, whereas autumn and winter samples gave the highest ash percentages. From the interaction, it is clear that the best CP and EE percentages (87.9 and 4.93, respectively) were recorded for fish muscles from sampling location No. 2 in winter.

Table 5: Overall means, standard errors, and probability level of muscular composition of Nile tilapia fish as affected by different sampling locations and seasons and their interaction.

\begin{tabular}{|c|c|c|c|c|c|}
\hline \multirow{2}{*}{ Treat. } & \multicolumn{5}{|c|}{ On dry matter basis (\%) } \\
\hline & Moisture & DM & $\mathbf{C P}$ & EE & Ash \\
\hline \multicolumn{6}{|l|}{ Location } \\
\hline 1 & 78.87 & 21.13 & 85.425 & 3.952 & 6.768 \\
\hline 2 & 78.80 & 21.20 & 85.650 & 3.975 & 6.781 \\
\hline 3 & 79.65 & 20.35 & 85.858 & 3.586 & 6.621 \\
\hline$\pm \mathrm{SE}$ & 0.780 & 0.780 & 0.399 & 0.217 & 0.078 \\
\hline P-value & 0.693 & 0.693 & 0.747 & 0.378 & 0.300 \\
\hline \multicolumn{6}{|l|}{ Season } \\
\hline Winter & 80.14 & 19.86 & $87.26 \mathrm{a}$ & $4.523 a$ & $6.740 \mathrm{ab}$ \\
\hline Spring & 77.40 & 22.61 & $84.97 \mathrm{~b}$ & $3.572 \mathrm{bc}$ & $6.549 \mathrm{~b}$ \\
\hline Summer & 79.22 & 20.78 & $85.12 b$ & $2.993 c$ & $6.618 b$ \\
\hline Autumn & 79.66 & 20.34 & $85.21 \mathrm{~b}$ & 4.261ab & $6.987 \mathrm{a}$ \\
\hline$\pm \mathrm{SE}$ & 0.901 & 0.901 & 0.461 & 0.250 & 0.091 \\
\hline P-value & 0.156 & 0.156 & 0.004 & 0.001 & 0.012 \\
\hline \multicolumn{6}{|c|}{ Location $x$ Season } \\
\hline $1 \times W$ & 78.76 & 21.24 & 86.933 & 4.557 & 6.644 \\
\hline 1xSp & 77.71 & 22.29 & 85.433 & 4.060 & 6.501 \\
\hline 1xSu & 80.09 & 19.92 & 84.633 & 3.527 & 6.905 \\
\hline $\mathbf{1 x A}$ & 78.92 & 21.09 & 84.700 & 3.663 & 7.022 \\
\hline $2 \times W$ & 78.72 & 21.28 & 87.900 & 4.930 & 6.895 \\
\hline 2xSp & 76.69 & 23.31 & 83.867 & 3.517 & 6.644 \\
\hline $2 \times S u$ & 80.72 & 19.28 & 85.600 & 3.170 & 6.627 \\
\hline $2 \times \mathbf{A}$ & 79.06 & 20.94 & 85.233 & 4.283 & 6.959 \\
\hline $3 x W$ & 82.95 & 17.05 & 86.967 & 4.083 & 6.680 \\
\hline $3 x S p$ & 77.79 & 22.22 & 85.633 & 3.140 & 6.504 \\
\hline $3 x S u$ & 76.87 & 23.14 & 85.133 & 2.283 & 6.322 \\
\hline $3 \mathbf{x A}$ & 81.00 & 19.00 & 85.700 & 4.837 & 6.980 \\
\hline$\pm \mathrm{SE}$ & 1.561 & 1.561 & 0.798 & 0.434 & 0.157 \\
\hline P-value & 0.182 & 0.182 & 0.578 & 0.165 & 0.410 \\
\hline
\end{tabular}

\section{Whole fish composition:}

Table 6 shows the chemical composition of tilapia carcass as affected by sampling locations and seasons as well as their interaction. There were no significant $(\mathrm{P} \geq 0.05)$ differences in chemical composition due to sampling locations; yet, there were significant $(\mathrm{P} \leq 0.05)$ differences in $\mathrm{CP}$ and $\mathrm{EE}$ due to sampling seasons. Since spring samples reflected higher CP (61.10) and winter samples gave the highest EE (24.94) percentages. From the interaction, it is clear that the best CP $(61.433 \%)$ was in location No. 2 in spring which presented the lowest EE (16.073\%). Actually, sometimes there were positive relationships between DM on one side and each of CP, $\mathrm{EE}$, and ash percentages on the other side. Also, there were negative relationships between CP on one hand and either EE or ash percentages on the other hand. These relationships were reported too by many authors (El-Ebiary and Zaki, 2003 and Abdelhamid et al., 2005a \& b and 2006b). 
The facts of the negative relationship between CP and EE from one side and between dry matter (DM) and CP on the other side were realized in this study. Also, there was a positive relationship between DM and EE contents. These relationships confirm those reported before that a negative relationship was noticed between CP and EE contents of fish body but a location relationship between CP and ash contents was recorded too (Abdelhamid et al., 2000). But Abdelhamid et al. (2009) found a negative correlation between protein and fat contents of the fish.

Abdelhamid et al. (2006b) reported also significant effects of sampling locations and seasons on all proximate analysis of fish body. They found that Port Saied and Marsa Matroh fish reflected higher $(\mathrm{P} \leq 0.05)$ protein than Alexandria and El-Bardawil fish. Yet, the fat and ash contents differed also but not in a clear trend. However, winter fish contained more protein and less fat percentages $\leq(\mathrm{P} 05)$ than those of summer. They attributed the elevated protein content in winter to the lower $(00.05)$ heavy metals content $(\mathrm{Pb}$ and $\mathrm{Fe}$ ) in fish flesh during this season than in summer. However, some significant correlations were calculated among heavy metals (in water, sediments, and fish) and chemical comomposition of the fish.

Table 6: Overall means, standard errors, and probability level of whole body composition of Nile tilapia fish as affected by different sampling locations and seasons and their interaction.

\begin{tabular}{|c|c|c|c|c|c|}
\hline \multirow{2}{*}{ Treat. } & \multicolumn{5}{|c|}{ On dry matter basis (\%) } \\
\hline & Moisture & DM & $\mathbf{C P}$ & $\mathbf{E E}$ & Ash \\
\hline \multicolumn{6}{|l|}{ Location } \\
\hline 1 & 70.86 & 29.14 & 56.992 & 20.291 & 5.937 \\
\hline 2 & 70.24 & 29.76 & 56.858 & 20.876 & 5.842 \\
\hline 3 & 71.06 & 28.94 & 56.375 & 20.851 & 5.958 \\
\hline$\pm \mathrm{SE}$ & 1.020 & 1.021 & 0.636 & 0.704 & 0.117 \\
\hline P-value & 0.837 & 0.837 & 0.773 & 0.803 & 0.761 \\
\hline \multicolumn{6}{|l|}{ Season } \\
\hline Winter & 70.74 & 29.26 & $56.81 b$ & $24.94 a$ & 6.144 \\
\hline Spring & 71.20 & 28.80 & $61.10 \mathrm{a}$ & $16.94 \mathrm{c}$ & 5.913 \\
\hline Summer & 70.00 & 30.00 & $56.67 \mathrm{~b}$ & $18.42 \mathrm{c}$ & 5.857 \\
\hline Autumn & 70.94 & 29.06 & $52.37 \mathrm{c}$ & $22.38 \mathrm{~b}$ & 5.733 \\
\hline$\pm \mathrm{SE}$ & 1.178 & 1.178 & 0.734 & 0.813 & 0.135 \\
\hline P-value & 0.901 & 0.901 & 0.0001 & 0.0001 & 0.213 \\
\hline \multicolumn{6}{|c|}{ Location $x$ Season } \\
\hline $1 \mathrm{xW}$ & 72.72 & 27.28 & 58.833 & 24.750 & 6.050 \\
\hline 1xSp & 71.70 & 28.30 & 60.800 & 18.477 & 6.473 \\
\hline $1 x S u$ & 70.33 & 29.67 & 56.100 & 17.090 & 5.493 \\
\hline $\mathbf{1 x A}$ & 68.70 & 31.31 & 52.233 & 20.847 & 5.730 \\
\hline $2 \times W$ & 67.95 & 32.05 & 57.567 & 26.840 & 6.183 \\
\hline $2 \mathrm{xSp}$ & 69.55 & 30.45 & 61.433 & 16.073 & 5.640 \\
\hline $2 \mathrm{xSu}$ & 69.72 & 30.28 & 55.567 & 20.977 & 6.057 \\
\hline $2 \mathbf{2 x A}$ & 73.73 & 26.27 & 52.867 & 19.613 & 5.487 \\
\hline $3 \times \mathbf{x W}$ & 71.56 & 28.44 & 54.033 & 23.240 & 6.200 \\
\hline $3 x S p$ & 72.35 & 27.65 & 61.067 & 16.277 & 5.627 \\
\hline $3 x S u$ & 69.94 & 30.06 & 58.367 & 17.203 & 6.020 \\
\hline $3 \mathbf{x A}$ & 70.40 & 29.60 & 52.033 & 26.683 & 5.983 \\
\hline$\pm \mathrm{SE}$ & 2.041 & 2.042 & 1.272 & 1.408 & 0.235 \\
\hline P-value & 0.344 & 0.344 & 0.163 & 0.006 & 0.0644 \\
\hline
\end{tabular}

\section{Fish heavy metals:}

\section{Fish muscles' heavy metals:}

Table 7 contains data of heavy metals levels (ppm) in tilapia muscles as affected by sampling locations and seasons as well as their interaction. The levels of $\mathrm{Pb}, \mathrm{Cd}$, and $\mathrm{F}$ were significantly $(\mathrm{P} \leq 0.05)$ affected by sampling locations, whereas $\mathrm{Zn}, \mathrm{Cd}, \mathrm{Fe}$, and $F$ significantly ( $\mathrm{P} \leq 0.05)$ affect ed by sampling seasons. From the interaction, it is clear that the highest values were reported for $\mathrm{Zn} \mathrm{(42.15)}$ and $\mathrm{Cu}$ (4.64) in fish muscles from location No. 3 in winter, Pb (8.16) location No. 2 in autumn, Cd (1.21) 
in location No. 2 in summer, Fe (73.08) in location No. 1 in summer, and F (6.995) in location No. 2 in autumn.

Table 7: Overall means (ppm), standard errors, and probability level of different heavy metals concentration of Nile tilapia muscles as affected by different sampling locations and seasons and their interaction.

\begin{tabular}{|c|c|c|c|c|c|c|}
\hline Treat. & Zn & $\mathbf{C u}$ & $\mathbf{P b}$ & Cd & $\mathbf{F e}$ & $\mathbf{F}$ \\
\hline \multicolumn{7}{|l|}{ Location } \\
\hline 1 & 24.65 & 3.33 & $0.00^{\mathbf{b}}$ & $0.38^{b}$ & 36.39 & $1.287^{\mathrm{b}}$ \\
\hline 2 & 26.81 & 3.66 & $3.79^{\mathrm{a}}$ & $0.72^{\mathbf{a}}$ & 31.07 & $3.455^{\mathrm{a}}$ \\
\hline 3 & 28.89 & 3.43 & $1.83^{\mathrm{ab}}$ & $0.53^{\mathrm{ab}}$ & 30.27 & $1.876^{b}$ \\
\hline$\pm \mathrm{SE}$ & 1.656 & 0.234 & 1.058 & 0.088 & 2.317 & 0.280 \\
\hline P-value & 0.203 & 0.586 & 0.047 & 0.026 & 0.136 & 0.0001 \\
\hline \multicolumn{7}{|l|}{ Season } \\
\hline Winter & $30.17^{\mathbf{a}}$ & 3.88 & 2.42 & $0.65^{a}$ & $23.24^{\mathrm{C}}$ & $0.35^{\mathrm{c}}$ \\
\hline Spring & $24.26^{\mathbf{b}}$ & 3.34 & 0.00 & $0.76^{\mathbf{a}}$ & $34.79^{\mathbf{b}}$ & $1.66^{\mathbf{b}}$ \\
\hline Summer & $31.00^{\mathrm{a}}$ & 3.37 & 2.35 & $0.58^{\mathrm{a}}$ & $51.60^{\mathbf{a}}$ & $2.40^{b}$ \\
\hline Autumn & $21.70^{\mathbf{b}}$ & 3.31 & 2.72 & $0.18^{b}$ & $20.69^{c}$ & $4.41^{\mathrm{a}}$ \\
\hline$\pm \mathrm{SE}$ & 1.912 & 0.271 & 1.221 & 0.102 & 2.675 & 0.323 \\
\hline P-value & 0.001 & 0.393 & 0.372 & 0.001 & 0.0001 & 0.0001 \\
\hline \multicolumn{7}{|c|}{ Location $x$ Season } \\
\hline $1 \times W$ & 26.45 & 3.46 & 0.00 & 0.41 & 23.18 & 0.390 \\
\hline 1xSp & 17.93 & 4.23 & 0.00 & 0.63 & 27.26 & 1.166 \\
\hline $1 \mathrm{xSu}$ & 35.99 & 2.36 & 0.00 & 0.46 & 73.08 & 1.107 \\
\hline $\mathbf{1 x A}$ & 18.22 & 3.26 & 0.00 & 0.01 & 22.03 & 2.485 \\
\hline $2 \times W$ & 21.90 & 3.55 & 0.00 & 0.45 & 20.67 & 0.132 \\
\hline $2 \mathrm{xSp}$ & 28.37 & 3.23 & 0.00 & 0.73 & 34.94 & 2.281 \\
\hline $2 \mathrm{xSu}$ & 27.64 & 4.33 & 6.98 & 1.21 & 49.72 & 4.411 \\
\hline $2 \times A$ & 29.33 & 3.55 & 8.16 & 0.51 & 18.96 & 6.995 \\
\hline $3 \mathbf{x W}$ & 42.15 & 4.64 & 7.25 & 1.10 & 25.87 & 0.529 \\
\hline $3 x S p$ & 26.48 & 2.55 & 0.00 & 0.91 & 42.15 & 1.535 \\
\hline $3 x S u$ & 29.37 & 3.42 & 0.07 & 0.09 & 32.01 & 1.684 \\
\hline $3 \mathbf{X A}$ & 17.55 & 3.12 & 0.00 & 0.03 & 21.06 & 3.755 \\
\hline \pm MSE & 3.312 & 0.469 & 2.116 & 0.177 & 4.634 & 0.560 \\
\hline P-value & 0.0001 & 0.010 & 0.010 & 0.0004 & 0.0001 & 0.0011 \\
\hline
\end{tabular}

\section{3- 2- Fish carcass' heavy metals:}

Table 8 contains data of heavy metals levels (ppm) in tilapia carcass as affected by sampling locations and seasons as well as their interaction. The levels of $\mathrm{Zn}, \mathrm{Cu}, \mathrm{Pb}, \mathrm{Fe}$, and F were significantly $(\mathrm{P} \leq 0.05)$ affected by sampling locations, whereas $\mathrm{Zn}, \mathrm{Cu}, \mathrm{Pb}, \mathrm{Fe}$, and $\mathrm{F}$ significantly $(\mathrm{P} \leq 0.05)$ affected by sampling seasons. From the interaction, it is clear that the highest values were reported for Zn (97.63) in whole fishbody from location No. 3 in summer, $\mathrm{Cu}(10.84)$ and $\mathrm{Fe}$ (5710) from location No. 1 in summer, Pb (10.51) location No. 1 in autumn, and Cd (0.95) and F (172.6) in location No. 3 in autumn. However, the commission regulation setting maximum $\mathrm{Pb}$ level for muscles of fish, released from the European communities, as $0.2 \mathrm{mg} / \mathrm{Kg}$ wet weight. Yet, the Egyptians' standards are $0.1 \mathrm{ppm} \mathrm{Pb}$ and $\mathrm{Cd}$ in food fish (ES, 1993). Abdelhakeem et al. (2002) cited the tolerance limits of Pb, Fe and Cd in fish water as $0.10,0.35$ and $0.10 \mathrm{ppm}$, respectively and in fish body as 2, 30 and $0.5 \mathrm{ppm}$, respectively .

\section{Bioaccumulation factor (BAF):}

\section{In fish muscles:}

Table 9 presents the BAF in fish muscles which ranged from $1.20 \times 10^{4}$ to $1.41 \times 10^{5}$ for $\mathrm{Zn}, 8.63 \times 10^{3}-1.63 \times 10^{5} \mathrm{Cu}, 1.24 \times 10^{3}-2.49 \times 10^{5} \mathrm{~Pb}, 0-0 \mathrm{Cd}$ and $4.29 \times 10^{3}-7.28 \times 10^{4}$ Fe. Fish muscles bioacumulated higher $\mathrm{Pb}$ than $\mathrm{Cu}, \mathrm{Fe}$, and $\mathrm{Zn}$, respectively. 
Table 8: Overall means (ppm), standard errors, and probability level of different heavy metals concentration of Nile tilapia carcass (whole body) as affected by different sampling locations and seasons and their interaction.

\begin{tabular}{|c|c|c|c|c|c|c|}
\hline Treat. & Zn & $\mathrm{Cu}$ & $\mathbf{P b}$ & Cd & Fe & $\mathbf{F}$ \\
\hline \multicolumn{7}{|l|}{ Location } \\
\hline 1 & $66.93^{b}$ & $8.05^{\mathrm{a}}$ & $5.12^{b}$ & 0.50 & $2492^{a}$ & $45.003^{\mathrm{C}}$ \\
\hline 2 & $79.31^{a}$ & $6.93^{\mathbf{b}}$ & $4.57^{b}$ & 0.45 & $1278^{b}$ & $68.461^{\mathrm{b}}$ \\
\hline 3 & $81.25^{\mathrm{a}}$ & $6.98^{b}$ & $10.24^{\mathrm{a}}$ & 0.70 & $875^{\mathrm{c}}$ & $83.190^{\mathrm{a}}$ \\
\hline$\pm \mathrm{SE}$ & 1.372 & 0.288 & 0.443 & 0.121 & 50.30 & 3.646 \\
\hline P-value & 0.0001 & 0.011 & 0.0001 & 0.321 & 0.0001 & 0.0001 \\
\hline \multicolumn{7}{|l|}{ Season } \\
\hline Winter & $62.69^{c}$ & $5.51^{d}$ & $4.60^{\mathrm{b}}$ & 0.51 & $614^{\mathrm{C}}$ & $48.59^{b}$ \\
\hline Spring & $84.26^{\mathbf{b}}$ & $6.72^{\mathrm{C}}$ & $2.83^{\mathrm{C}}$ & 0.39 & $428^{d}$ & $52.47^{\mathbf{b}}$ \\
\hline Summer & $94.17^{a}$ & $9.09^{\mathrm{a}}$ & $5.78^{b}$ & 0.67 & $3310^{a}$ & $45.95^{b}$ \\
\hline Autumn & $62.21^{\mathrm{c}}$ & $7.98^{b}$ & $13.37^{\mathrm{a}}$ & 0.62 & $1841^{b}$ & $115.19^{\mathrm{a}}$ \\
\hline$\pm \mathrm{SE}$ & 1.584 & 0.333 & 0.512 & 0.140 & 58.09 & 4.210 \\
\hline P-value & 0.0001 & 0.0001 & 0.0001 & 0.504 & 0.0001 & 0.0001 \\
\hline \multicolumn{7}{|c|}{ Location x Season } \\
\hline $1 \times W$ & 57.73 & 5.97 & 3.51 & 0.36 & 324 & 51.93 \\
\hline 1xSp & 74.14 & 6.84 & 1.92 & 0.60 & 269 & 49.81 \\
\hline $1 \mathrm{xSu}$ & 91.14 & 10.84 & 4.55 & 0.62 & 5710 & 37.11 \\
\hline 1xA & 44.74 & 8.57 & 10.51 & 0.44 & 3666 & 41.16 \\
\hline $2 \times W$ & 58.98 & 4.92 & 5.47 & 0.42 & 305 & 44.99 \\
\hline $2 \mathrm{xSp}$ & 86.84 & 5.60 & 1.45 & 0.29 & 145 & 53.40 \\
\hline $2 \mathrm{xSu}$ & 93.74 & 8.69 & 6.39 & 0.60 & 3494 & 43.62 \\
\hline $2 \mathrm{xA}$ & 77.68 & 8.52 & 4.99 & 0.47 & 1170 & 131.83 \\
\hline $3 \times W$ & 71.37 & 5.64 & 4.81 & 0.76 & 1214 & 48.84 \\
\hline $3 x \mathrm{Sp}$ & 91.80 & 7.71 & 5.11 & 0.28 & 870 & 54.20 \\
\hline $3 x S u$ & 97.63 & 7.73 & 6.40 & 0.79 & 727 & 57.11 \\
\hline $3 \mathbf{X A}$ & 64.20 & 6.84 & 24.62 & 0.95 & 689 & 172.60 \\
\hline$\pm \mathrm{SE}$ & 2.744 & 0.576 & 0.887 & 0.243 & 100.6 & 7.292 \\
\hline P-value & 0.0001 & 0.007 & 0.0001 & 0.741 & 0.0001 & 0.0001 \\
\hline
\end{tabular}

Table 9: Bioaccumulation factor (dividing the element level in fish muscles by the same element level in the water and multiplying by 100) of different heavy metals in Nile tilapia muscles as affected by different sampling locations and seasons and their interaction.

\begin{tabular}{|c|c|c|c|c|c|}
\hline Location/season & Zn & Cu & Pb & Cd & Fe \\
\hline 1 & $7.25 \times 10^{4}$ & $1.75 \times 10^{4}$ & 0 & 0 & $6.45 \times 10^{3}$ \\
\hline 2 & $5.96 \times 10^{4}$ & $1.66 \times 10^{4}$ & $2.49 \times 10^{5}$ & 0 & $1.35 \times 10^{4}$ \\
\hline 3 & $9.63 \times 10^{4}$ & $4.29 \times 10^{4}$ & $1.24 \times 10^{3}$ & 0 & $1.23 \times 10^{4}$ \\
\hline Winter & $9.14 \times 10^{4}$ & $2.43 \times 10^{4}$ & $1.95 \times 10^{3}$ & 0 & $1.83 \times 10^{4}$ \\
\hline Spring & $6.1 \times 10^{4}$ & $1.39 \times 10^{4}$ & 0 & 0 & $8.59 \times 10^{3}$ \\
\hline Summer & $6.33 \times 10^{4}$ & $1.69 \times 10^{4}$ & $1.24 \times 10^{3}$ & 0 & $7.95 \times 10^{3}$ \\
\hline Autumn & $9.43 \times 10^{4}$ & $6.62 \times 10^{4}$ & $1.86 \times 10^{3}$ & 0 & $9.95 \times 10^{3}$ \\
\hline $1 \times W$ & $9.12 \times 10^{4}$ & $2.47 \times 10^{4}$ & 0 & 0 & $1.1 \times 10^{4}$ \\
\hline $1 \times S P$ & $3.20 \times 10^{4}$ & $8.63 \times 10^{3}$ & 0 & 0 & $2.96 \times 10^{4}$ \\
\hline $1 \times S U$ & $1.20 \times 10^{4}$ & $2.15 \times 10^{4}$ & 0 & 0 & $5.1 \times 10^{3}$ \\
\hline $1 \times A$ & $8.68 \times 10^{4}$ & $1.63 \times 10^{5}$ & 0 & 0 & $4.29 \times 10^{3}$ \\
\hline $1 \times W$ & $5.76 \times 10^{4}$ & $1.61 \times 10^{4}$ & 0 & 0 & $2.04 \times 10^{4}$ \\
\hline $2 \times S P$ & $1.01 \times 10^{5}$ & $2.02 \times 10^{4}$ & 0 & 0 & $1.23 \times 10^{4}$ \\
\hline $2 \times S U$ & $3.07 \times 10^{4}$ & $1.06 \times 10^{4}$ & $4.26 \times 10^{3}$ & 0 & $1.10 \times 10^{4}$ \\
\hline $2 \times A$ & $1.22 \times 10^{5}$ & $3.55 \times 10^{4}$ & $5.48 \times 10^{3}$ & 0 & $2.67 \times 10^{4}$ \\
\hline $3 \times W$ & $1.41 \times 10^{5}$ & $4.22 \times 10^{4}$ & $6.19 \times 10^{3}$ & 0 & $2.24 \times 10^{4}$ \\
\hline $3 \times S P$ & $7.61 \times 10^{4}$ & $3.19 \times 10^{4}$ & 0 & 0 & $5.01 \times 10^{3}$ \\
\hline $3 \times S U$ & $1.1 \times 10^{5}$ & $4.88 \times 10^{4}$ & 0 & 0 & $7.28 \times 10^{4}$ \\
\hline $3 \times A$ & $7.31 \times 10^{4}$ & $7.80 \times 10^{4}$ & 0 & 0 & $5.54 \times 10^{4}$ \\
\hline
\end{tabular}

\section{In whole fish carcass:}

Table 10 presents the BAF of different heavy metals in the whole carcass of Nile tilapia fish tested in the present work. It ranged between $1.04 \times 10^{5}-3.62 \times 10^{5}$ for $\mathrm{Zn}$, $1.39 \times 10^{4}-1.59 \times 10^{5} \mathrm{Cu}, 1.55 \times 10^{3}-1.79 \times 10^{4} \mathrm{~Pb}, 0-0 \mathrm{Cd}$, and $1.79 \times 10^{4}-8.85$ $\mathrm{x} 10^{5} \mathrm{Fe}$. That means that Fe bioaccumulated at highest in the whole fish body 
followed by $\mathrm{Zn}, \mathrm{Cu}$ and $\mathrm{Pb}$, respectively. Comparing with the previous Table 9, it is clear that each of $\mathrm{Zn}, \mathrm{Cu}$, and $\mathrm{Fe}$ are more bioaccumulated in the whole fish body than in the fish muscles. This may depend on the target organ for each element where it deposits.

Table 10: Bioaccumulation factors (dividing the element level in whole fish by the same element level in the water and multiplying by 100) of different heavy metals in whole Nile tilapia carcass as affected by different sampling locations and seasons and their interaction.

\begin{tabular}{|c|c|c|c|c|c|}
\hline Location/season & $\mathbf{Z n}$ & $\mathbf{C u}$ & $\mathbf{P b}$ & $\mathbf{C d}$ & $\mathbf{F e}$ \\
\hline 1 & $1.97 \times 10^{5}$ & $4.24 \times 10^{4}$ & $3.53 \times 10^{3}$ & 0 & $4.42 \times 10^{5}$ \\
\hline 2 & $1.76 \times 10^{5}$ & $3.15 \times 10^{4}$ & $3.1 \times 10^{3}$ & 0 & $5.53 \times 10^{5}$ \\
\hline 3 & $2.71 \times 10^{5}$ & $8.73 \times 10^{4}$ & $6.97 \times 10^{3}$ & 0 & $3.54 \times 10^{5}$ \\
\hline Winter & $1.89 \times 10^{5}$ & $3.44 \times 10^{4}$ & $3.71 \times 10^{3}$ & 0 & $4.82 \times 10^{5}$ \\
\hline Spting & $2.11 \times 10^{5}$ & $2.80 \times 10^{4}$ & $1.81 \times 10^{3}$ & 0 & $1.1 \times 10^{5}$ \\
\hline Summr & $1.92 \times 10^{5}$ & $4.55 \times 10^{4}$ & $3.50 \times 10^{3}$ & 0 & $5.10 \times 10^{5}$ \\
\hline Autumn & $2.70 \times 10^{5}$ & $1.59 \times 10^{5}$ & $9.16 \times 10^{3}$ & 0 & $8.85 \times 10^{5}$ \\
\hline $1 \times \mathrm{x} \mathrm{w}$ & $1.99 \times 10^{5}$ & $2.26 \times 10^{4}$ & $3.72 \times 10^{3}$ & 0 & $1.49 \times 10^{5}$ \\
\hline $1 \mathrm{xSp}$ & $1.32 \times 10^{5}$ & $1.39 \times 10^{4}$ & $1.55 \times 10^{3}$ & 0 & $2.92 \times 10^{5}$ \\
\hline $1 \times \mathrm{Au}$ & $3.03 \times 10^{5}$ & $9.85 \times 10^{4}$ & $2.59 \times 10^{3}$ & 0 & $3.99 \times 10^{5}$ \\
\hline $1 \times \mathrm{A}$ & $2.13 \times 10^{5}$ & $4.29 \times 10^{4}$ & $6.96 \times 10^{3}$ & 0 & $7.13 \times 10^{5}$ \\
\hline $2 \mathrm{x} \mathrm{w}$ & $1.55 \times 10^{5}$ & $2.24 \times 10^{4}$ & $4.31 \times 10^{3}$ & 0 & $3.01 \times 10^{5}$ \\
\hline $2 \mathrm{xSp}$ & $3.1 \times 10^{5}$ & $3.50 \times 10^{4}$ & $8.96 \times 10^{3}$ & 0 & $5.12 \times 10^{5}$ \\
\hline $2 \mathrm{x} \mathrm{Au}$ & $1.04 \times 10^{5}$ & $2.12 \times 10^{4}$ & $3.89 \times 10^{3}$ & 0 & $7.43 \times 10^{5}$ \\
\hline $2 \mathrm{x} \mathrm{A}$ & $3.24 \times 10^{5}$ & $8.52 \times 10^{4}$ & $3.35 \times 10^{3}$ & 0 & $1.64 \times 10^{5}$ \\
\hline $3 \times \mathrm{x}$ & $2.38 \times 10^{5}$ & $5.13 \times 10^{4}$ & $4.11 \times 10^{3}$ & 0 & $1.99 \times 10^{5}$ \\
\hline $3 \mathrm{xSp}$ & $2.48 \times 10^{5}$ & $9.64 \times 10^{4}$ & $2.87 \times 10^{3}$ & 0 & $1.03 \times 10^{5}$ \\
\hline $3 \mathrm{xu}$ & $3.62 \times 10^{5}$ & $1.10 \times 10^{5}$ & $4.16 \times 10^{3}$ & 0 & $1.65 \times 10^{5}$ \\
\hline $3 \times \mathrm{A}$ & $2.68 \times 10^{5}$ & $1.71 \times 10^{5}$ & $1.79 \times 10^{4}$ & 0 & $1.81 \times 10^{5}$ \\
\hline
\end{tabular}

Abdelhamid (1994 and 2009a) cited that heavy metals are harmful, so $\mathrm{Cu}$, for example, leads to discoloration, degrowth, congestion of gills, liver, and lower digestive tract, and damaged kidneys and liver of fish. Yet, Abdelhakeem et al. (2002) classified the fluorine as not critical element; whereas $\mathrm{Cu}, \mathrm{Cd}, \mathrm{Pb}$ and $\mathrm{Zn}$ as very toxic elements. So, they gave the following permissible levels in ppm in fish:

$\begin{array}{ll}\text { Element } & \text { Toler } \\ \mathrm{Cd} & 0.50 \\ \mathrm{Cu} & 20.0 \\ \mathrm{Fe} & 30.0 \\ \mathrm{~Pb} & 2.00 \\ \mathrm{Zn} & 40.0\end{array}$

The concentration of some heavy metals (Fe, $\mathrm{Zn}, \mathrm{Cu}, \mathrm{Pb}, \mathrm{Cd}$ and $\mathrm{Co}$ ) in water and liver, gills, intestine, testis, heart and muscle of $O$. niloticus and L. niloticus obtained from four khors (El-Ramla, Kalabsha, Korosko and Toushka) of Lake Nasser, Egypt, during 2006 was investigated (using atomic absorption spectrophotometry) with emphasis on the histological alterations in these organs. Metal concentrations in the water of khors (mg/l) followed an abundance of: Fe > $\mathrm{Zn}>\mathrm{Pb}>\mathrm{Cu}>\mathrm{Cd}>\mathrm{Co}$. The highest values of metals were reported in khor Toushka. It was found that the metals were accumulated in different tissues of both fish by various levels, where, the non-edible parts accumulated more metals than the edible muscles. $\mathrm{Zn}, \mathrm{Cu}, \mathrm{Pb}$ and $\mathrm{Cd}$ concentrations in the fish muscles were below the maximum permissible limit, however, Fe in the muscles exceeded the permissible limit. Several histopathological alterations, including vacuolar degeneration with focal areas of necrosis in liver, proliferation in the epithelium of gill filaments and fusion of secondary lamellae, severe degenerative and necrotic changes in the intestinal mucosa and seminiferous tubules, degeneration and atrophy in cardiac muscle fibers and 
degeneration in muscle bundles were observed in the studied tissues of both fish as a result of the accumulated metals (Mohamed, 2008).

The concentrations of heavy metals including $\mathrm{Fe}, \mathrm{Zn}, \mathrm{Cu}, \mathrm{Mn}, \mathrm{Cd}$ and $\mathrm{Pb}$ in water and sediments in northern Delta Lakes (Edku, Borollus and Manzala) and their accumulation in Nile tilapia (Oreochromis niloticus) organs (muscle, gills and liver) were investigated. Water, sediments and fish organs from Lake Manzala showed greater concentrations of most of the studied metals than those from Lake Edku and Lake Borollus. Fe, Mn, $\mathrm{Cd}$ and $\mathrm{Pb}$ (in Lake Manzala) and $\mathrm{Mn}$ and $\mathrm{Pb}$ in Lake Borollus recorded levels above the international permissible limits in water. In sediment samples Mn (in Lake Edku) and Cd (in Lake Manzala) recorded higher values than the sediment quality guidelines. Gills and Liver of O. niloticus contained the highest concentration of most the detected heavy metals, while muscles appeared to be the last preferred site for the bioaccumulation of metals. The edible part of $O$. niloticus showed higher levels of Cd (in Lake Edku and Manzala) and $\mathrm{Pb}$ (in Lake Manzala). Nile tilapia caught from these two Lakes may pose health hazards for consumers (Saeed and Shaker, 2008).

Concentrations of some heavy metals $(\mathrm{Pb}, \mathrm{Cd}, \mathrm{Hg}, \mathrm{Cu}$ and $\mathrm{Cr}$ ) were determined in water, sediment and tissues of tilapia fish collected from Wadi Hanifah during summer 2010. The concentrations of the heavy metal in water were within the international permissible level. $\mathrm{Cu}$ had the highest accumulating level in fish. The transfer factors of all metals in fish from water were greater than those from sediments. This led to the conclusion that fish bioaccumulation with these metals was from water. Heavy metals in the edible parts of tilapia were within the safety permissible level for human use (Abdel-Baki et al., 2011).

On Rosetta branch of River Nile in Egypt, there are some industrial cities e.g. Kafr El-Zyat city. To address questions of water quality and to suggest a low cost and available treatment process for some toxic metals (iron, manganese, zinc, copper, lead and cadmium), water samples from surface and bottom layers were collected at 3 stations and 3 drains. The results showed that the concentration of these metals are higher than the permissible levels due to the discharges of two industrial companies in this area (El-Malyia \& Soda and Salt). The treated water can pass into River Nile safely and without any pollution for fish or sediment and the water quality remains good without any harmful risk throughout its usage (Daifullah et al., 2013).

\section{Heavy metals in water, fish muscles, and whole fishbody:}

Table 11 illustrates the correlation coefficients between heavy metal levels in the River Nile water, tilapia muscles, and tilapia whole body. There were significantly positive correlations between $\mathrm{Pb} / \mathrm{Cu}$ and $\mathrm{Pb} / \mathrm{Cd}$ in fish muscles, whole fish $\mathrm{Zn} /$ muscular $\mathrm{Fe}, \mathrm{Cd} / \mathrm{Cu}$ in whole fish, $\mathrm{Cd} / \mathrm{Pb}$ in whole fish, whole fish $\mathrm{Fe} /$ muscular $\mathrm{Fe}, \mathrm{Cu} / \mathrm{Fe}$ in whole fish, water $\mathrm{Zn} /$ muscular $\mathrm{Cd}$, water $\mathrm{Cu} /$ muscular $\mathrm{Cu}, \mathrm{Cu} / \mathrm{Zn}$ in water, water $\mathrm{Fe} /$ muscular $\mathrm{Fe}$, water $\mathrm{Fe}$ /whole fish $\mathrm{Cu}$, water $\mathrm{Fe} /$ whole fish $\mathrm{Fe}$, and $\mathrm{Fe} / \mathrm{Pb}$ in water. Also, there were significantly negative correlations between water $\mathrm{Cu} /$ whole fish $\mathrm{Pb}$ and water Fe/muscular Cu. However, Saeed and Mohammed (2012) correlated between physico-chemical parameters of water and levels of some heavy metals ( $\mathrm{Cd}, \mathrm{Cu}, \mathrm{Fe}, \mathrm{Pb}$, and $\mathrm{Zn}$ ) accumulated in water and fish tissues. They found no strong correlation between fish metals concentration and some water quality parameters. Yet, electric conductivity had a negative effect on accumulation of Cd and $\mathrm{Pb}$ in gills and liver tissues. The concentrations of $\mathrm{Cu}, \mathrm{Fe}$, and $\mathrm{Zn}$ in water and edible part of fish were found below the notified toxic limits. 
Table 11: Pearson correlation between different heavy metals concentration in Nile tilapia muscles and carcass (whole body) as well as in water regardless of sampling locations and seasons.

\begin{tabular}{|c|c|c|c|c|c|c|c|c|c|c|c|c|c|c|c|}
\hline & & \multicolumn{5}{|c|}{ Muscles } & \multicolumn{5}{|c|}{ Fish } & \multicolumn{4}{|c|}{ Water } \\
\hline & & Zn & $\mathrm{Cu}$ & $\mathbf{P b}$ & Cd & $\mathbf{F e}$ & Zn & $\mathrm{Cu}$ & $\mathbf{P b}$ & Cd & $\mathbf{F e}$ & Zn & $\mathrm{Cu}$ & $\mathbf{P b}$ & Cd \\
\hline \multirow{8}{*}{ 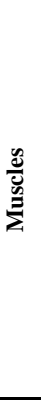 } & $\mathrm{Cu}$ & -0.057 & & & & & & & & & & & & & \\
\hline & & 0.743 & & & & & & & & & & & & & \\
\hline & $\mathbf{P b}$ & 0.010 & 0.551 & & & & & & & & & & & & \\
\hline & & 0.952 & 0.001 & & & & & & & & & & & & \\
\hline & Cd & 0.095 & 0.496 & 0.772 & & & & & & & & & & & \\
\hline & & 0.581 & 0.002 & 0.000 & & & & & & & & & & & \\
\hline & $\mathrm{Fe}$ & 0.280 & -0.139 & -0.035 & 0.084 & & & & & & & & & & \\
\hline & & 0.098 & 0.417 & 0.838 & 0.627 & & & & & & & & & & \\
\hline \multirow{10}{*}{$\overline{\text { sี }}$} & Zn & 0.250 & -0.055 & 0.097 & 0.261 & 0.500 & & & & & & & & & \\
\hline & & 0.142 & 0.752 & 0.573 & 0.123 & 0.002 & & & & & & & & & \\
\hline & $\mathrm{Cu}$ & -0.027 & -0.126 & 0.135 & -0.080 & 0.559 & 0.312 & & & & & & & & \\
\hline & & 0.876 & 0.463 & 0.432 & 0.643 & 0.000 & 0.064 & & & & & & & & \\
\hline & $\mathbf{P b}$ & -0.276 & -0.032 & -0.063 & -0.322 & -0.183 & -0.321 & 0.016 & & & & & & & \\
\hline & & 0.103 & 0.852 & 0.717 & 0.056 & 0.285 & 0.057 & 0.927 & & & & & & & \\
\hline & Cd & -0.039 & 0.096 & 0.041 & -0.183 & 0.042 & -0.049 & 0.385 & 0.349 & & & & & & \\
\hline & & 0.821 & 0.579 & 0.812 & 0.286 & 0.806 & 0.776 & 0.020 & 0.037 & & & & & & \\
\hline & $\mathbf{F e}$ & 0.167 & -0.184 & 0.030 & -0.048 & 0.571 & 0.095 & 0.663 & 0.035 & 0.069 & & & & & \\
\hline & & 0.330 & 0.283 & 0.860 & 0.779 & 0.000 & 0.582 & 0.000 & 0.838 & 0.690 & & & & & \\
\hline \multirow{10}{*}{ 录 } & Zn & -0.022 & 0.250 & 0.180 & 0.416 & 0.232 & 0.329 & 0.092 & -0.201 & 0.002 & 0.104 & & & & \\
\hline & & 0.898 & 0.141 & 0.295 & 0.012 & 0.174 & 0.050 & 0.594 & 0.240 & 0.989 & 0.547 & & & & \\
\hline & $\mathrm{Cu}$ & -0.141 & 0.350 & 0.081 & 0.319 & 0.100 & 0.197 & -0.077 & -0.365 & -0.023 & -0.119 & 0.797 & & & \\
\hline & & 0.414 & 0.036 & 0.641 & 0.058 & 0.562 & 0.249 & 0.654 & 0.029 & 0.895 & 0.488 & 0.000 & & & \\
\hline & $\mathbf{P b}$ & 0.061 & -0.347 & -0.075 & 0.067 & 0.568 & 0.608 & 0.511 & -0.092 & -0.143 & 0.468 & 0.118 & -0.200 & & \\
\hline & & 0.722 & 0.038 & 0.664 & 0.696 & 0.000 & 0.000 & 0.001 & 0.592 & 0.404 & 0.004 & 0.494 & 0.243 & & \\
\hline & Cd & $\mathrm{x}$ & $\mathrm{x}$ & $\mathrm{x}$ & $\mathrm{x}$ & $\mathrm{x}$ & $\mathrm{x}$ & $\mathrm{x}$ & $\mathrm{x}$ & $\mathrm{x}$ & $\mathrm{x}$ & $\mathrm{x}$ & $\mathrm{x}$ & $\mathrm{x}$ & \\
\hline & & $\mathrm{x}$ & $\mathrm{x}$ & $\mathrm{x}$ & $\mathrm{x}$ & $\mathrm{x}$ & $\mathrm{x}$ & $\mathrm{x}$ & $\mathrm{x}$ & $\mathrm{x}$ & $\mathrm{x}$ & $\mathrm{x}$ & $\mathrm{x}$ & $\mathrm{x}$ & \\
\hline & $\mathrm{Fe}$ & 0.179 & -0.344 & -0.126 & 0.098 & 0.684 & 0.306 & 0.527 & -0.158 & -0.104 & 0.768 & 0.057 & -0.136 & 0.702 & $\mathrm{x}$ \\
\hline & & 0.295 & 0.040 & 0.465 & 0.569 & 0.000 & 0.069 & 0.001 & 0.357 & 0.546 & 0.000 & 0.739 & 0.428 & 0.000 & $\mathrm{x}$ \\
\hline
\end{tabular}

Cell Contents: Pearson correlation

P-Value

$\mathrm{X}$ : All values in column are identical.

Zyadah (1997) reported significant effects on water mineral contents (containing $\mathrm{Cd}$ and $\mathrm{Pb}$ ) due to different locations and seasons. Also, he found high levels of heavy metals in the sediment and fish, exceeded the permissible limit. Yet, AboulNaga (2000) reported high trace metal concentrations in front of El-Tabia Pumping Station. Iron was the dominant metal in all humic acids and sediments examined. Humic acids are trace metals holders in the sediments, therefore humic acids play a major role in the geochemical cycling of the elements in the aquatic environment. Abdelhakeem et al. (2002) cited the tolerance limits of $\mathrm{Pb}, \mathrm{Fe}$ and $\mathrm{Cd}$ in fish water as $0.10,0.35$ and $0.10 \mathrm{ppm}$, respectively and in fish body as 2, 30 and 0.5 ppm, respectively. Heavy metal concentrations in fish varied significantly depending on the type of the tissue, fish species and sampling location. 
Moreover, Abdelhamid et al. (2013) reported that elements took the following descending order: $\mathrm{Fe} \geq \mathrm{Pb} \geq \mathrm{Zn} \geq \mathrm{Cu} \geq \mathrm{Cd}$ in the fish carcass. However, the element's concentrations took the following ranges: $0.00-209.00,0.00-10.00,0.00-51.03$, $56.00-95.00$, and $479-1895$ ppm, respectively. This reflects that the presence of a heavy metal in a fish body may not be followed its presence in the surroundings sediments or water. It may depend on its solubility, target medium, site of its location, as well as on different water quality criteria (salinity, $\mathrm{pH}$, alkalinity, dissolved oxygen, microbial load....etc), sediment and fish species (differing in the metabolism). Also, $\mathrm{Cd}$ was at least in sediments and fish, but $\mathrm{Cu}$ was at least in water. This may be interpretable by calculating the BAF of these elements which were $2.57 \times 10^{4}, 1.66 \times 10^{2}, 1.33 \times 10^{4}, 4.12 \times 10^{3}$ and $7.49 \times 10^{5}$ for $\mathrm{Pb}, \mathrm{Cd}, \mathrm{Cu}, \mathrm{Zn}$ and $\mathrm{Fe}$, respectively, i.e. Fe was the heaviest element in the fish body, followed by $\mathrm{Pb}, \mathrm{Zn}, \mathrm{Cu}$ and at least $\mathrm{Cd}$ as mentioned before.

In this respect, the BAF of different heavy metals tested) in the M. cephalus studied from four sampling locations during two seasons showed significantly highest $\mathrm{BAF}$ in fish from Alexandria, Port Saied and El-Bardawil for $\mathrm{Pb}, \mathrm{Fe}$ and $\mathrm{Cd}$, respectively. Winter $\mathrm{Pb}-\mathrm{BAF}$ and summer $\mathrm{Fe}-\mathrm{BAF}$ were significantly higher than those of the other season. These BAFs of heavy metals in fish did not influence by the level of these metals in the fish rearing waters. The highest BAF of Fe in Port Saied fish samples was related also to the highest Fe contents in fish of this location. The same relation was confirmed for $\mathrm{Cd}$ in El-Bardawil fish samples, but not for $\mathrm{Pb}$ (Abdelhamid et al., 2006b).

However, the commission regulation setting maximum $\mathrm{Pb}$ level for muscles of fish, released from the European communities, as $0.2 \mathrm{mg} / \mathrm{Kg}$ wet weight. Yet, the Egyptians' standards are $0.1 \mathrm{ppm} \mathrm{Pb}$ and Cd in food fish (ES, 1993). Comparing these standards with the levels obtained herein, it would be indicated that there is a water pollution with heavy metals in all tested locations, particularly with $\mathrm{Pb}$ in summer, $\mathrm{Fe}$ in winter and Cd in both seasons and all locations. Abdelhakeem et al. (2002) cited the tolerance limits of $\mathrm{Pb}, \mathrm{Fe}$ and $\mathrm{Cd}$ in fish water as $0.10,0.35$ and $0.10 \mathrm{ppm}$, respectively and in fish body as 2, 30 and $0.5 \mathrm{ppm}$, respectively. Heavy metal concentrations in fish varied significantly depending on the type of the tissue, fish species and sampling location.

Generally, Mugil cephalus L. showed higher levels of Fe and Pb concentrations than Sparus aurata L. (Yilmaz, 2005). This may be due to the store tissue of each metal in the fish, i.e. $\mathrm{Pb}$ is probably an external pollutant (Rashed and Awadallah, 1994), whereas Fe and Cd were internal pollutants. Therefore, Fe and Cd contents of fish affected positively their BAFs, but $\mathrm{Pb}$ was not. The same note is available for the effect of season, since BAF of Pb did not influence by its level in/or on the fish, whereas BAF of Fe was correlated with its level in fish, being the highest in summer season. Also, there were remarkable effects on microelements of fish muscles as well as their bioaccumulation factors due to sampling seasons and locations and fish species (Abdelhamid and El-Zareef, 1996).

Seasonal and location variations as well as fish species' effects were reported before by Abdelhamid et al. (2006b), who found that the highest ( $\$ 0.05)$ levels of the tested heavy metals were found in fish collected from Marsa Matroh (0.851 ppm $\mathrm{Pb}$ ), Port Saied (2.40 ppm Fe) and El-Bardawil (0.081 ppm Cd). This may be related to the high content of $\mathrm{Pb}$ in water and sediments collected from location No. 1 during both seasons. Also, Fe level of the summer diet and winter collected sediments from Port Saied were the highest. Cd level in El-Bardawil sediment collected in summer was also the highest. The Fe concentrations range $(1.3-2.4 \mathrm{ppm})$ of fish tested was 
higher than that of $\mathrm{Pb}(0.172-0.851 \mathrm{ppm})$ than $\mathrm{Cd}(0.016-0.081 \mathrm{ppm})$, regardless to the sampling locations.

However, Abdelhamid et al. (1997) registered significant variations in heavy metals concentrations due to different fish species from the natural fisheries and to sampling locations too. They found that the elements' concentrations in the sediments and fishes were much higher than the corresponding values in the water, particularly for iron. Lead and cadmium levels in fish muscles were concentrated more in fish, while iron was highest in sediments followed by fish tissues. Mugil cephalus samples were more frequently contaminated than Liza ramada and Sparus aurata (Abdelhamid et al., 1997). The effects of varying sampling locations and fish parts on the heavy metal level or presence were reported also by Abdelhamid et al. (2000).

Anyhow, Cd is known to be human carcinogen (Mandel et al., 1995), Bahr ElBakar drain water contained 0.910 and $0.0242 \mathrm{mg} / \mathrm{l} \mathrm{Pb}$ and Cd, respectively, whereas its $M$. cephalus fish flesh contained 0.9376 and $0.0324 \mathrm{mg} / \mathrm{Kg} \mathrm{Pb}$ and Cd, respectively (Galhoom et al., 2000). Additionally, Salem (2003) found that $\mathrm{Cd}$ and $\mathrm{Pb}$ caused significant reduction in fish performance, survival, and muscular area. $\mathrm{Cd}$ and $\mathrm{Pb}$ ions were able to induce metallothionein gene expression in fish tissues, e.g. liver and gills (Cheung et al., 2004). Its residues in fish flesh increased by dose increase. The protein banding patterns fluctuated in numbers and intensities by $\mathrm{Cd}$ concentrations. Generally, Mugil cephalus L. showed higher levels of $\mathrm{Fe}$ and $\mathrm{Pb}$ concentrations than Sparus aurata L. (Yilmaz, 2005).

To interpret the collective death of fish in Domietta region, it was proved that the water of the studied area (El-Bostan village - Kafr El-Batiekh) has suffered from increase of iron concentrations. This picture is very harmful to fish life and production. Pollution of water was reflected in the form of heavy metal accumulation in different fish tissues. The lowest bioaccumulation factors were calculated in fish muscles; therefore, muscles only are suitable for human consumption. The bioconcentration of iron was higher than that of lead in fish muscles (Abdelhamid et al., 2000).

However, any degree of poisoning will weaken the fish, making it vulnerable towards disease. Heavy metals can create problems and be concentrated in waterway organisms up to 9100 times more than the surrounding environment's levels, so may lead to acute or chronic effects (WRC, 2005).

Also, it is a fact that body adaptive balance mechanisms for lead impacts were evident in different organ tissues of fish. Yet, Mzimela et al. (2002) reported that lead negatively affected the blood hematology and acid-base balance of the groovy mullet, Liza dumerili. Significant correlations were obtained for the levels of numerous metals in water, sediment and fish. The results of Xie and Klerks (2004) suggest that reduced uptake and accumulation of $\mathrm{Cd}$ accounted for approximately two-third of the increased resistance in the Cd-adapted lines of fish. However, $\mathrm{Cd}$ has been found to accumulate in reproductive organs of fish and disrupt important endocrine processes.

Kirby et al. (2001) mentioned that mullet are directly exposed to trace metal concentrations as a result of feeding and the ingestion of contaminated sediment and detritus. Lower metal concentrations found in mullet tissues are attributed to the burial of highly contaminated sediment with material containing lower trace metal concentrations.

Siam (2001) found high level of accumulation of $\mathrm{Cd}, \mathrm{Fe}$ and $\mathrm{Pb}$ in the different organs (gills, liver, stomach and brain) of Alexandria coast fish, with respect to their corresponding in the muscle tissues. He added that the accumulation factors for these metals were higher in the herbivorous fish (Siganus rivulatus) than in the carnivorous 
ones (Mugil capito). Fe was the more pronounced one reflecting increase the trophic level of the fish. Cd level was generally lower than that of $\mathrm{Pb}$ in various organs while brain gained the highest values. Pb concentration ranged from 1.2 to $3.5 \mathrm{mg} / \mathrm{kg}$ in the stomach and brain while it ranged from 0.4 to $0.9 \mathrm{mg} / \mathrm{kg}$ in fish muscles.

Most of the fish generally showed levels of Cd in the organs, which are close to that of the recommended standard $(2.0 \mathrm{mg} / \mathrm{kg})$ of the National Health and Medical Council in Australia. However, none of them contained Cd concentrations above 0.5 $\mathrm{mg} / \mathrm{kg}$ in their muscle tissues. Total length, body weight and age are mostly correlated biometric parameters with metallothionein and soluble metal concentrations in striped red mullet and golden grey mullet (Filipovic and Raspor, 2003). Cadmium and lead were higher in muscular tissue from mullet (Mugil sp.) than snook (Centropomus sp.) and higher in summer than in winter (Joyeux et al., 2004). Staniskiene et al. (2005) found high concentrations of $\mathrm{Fe}$ in 15 fish species as a direct result of water contamination with heavy metals. Metal concentrations were found to be influenced by fish species.

Saeed and Mohammed (2012) concluded that chemical characteristics strongly influenced bioaccumulation of metals in water with no strong correlation between fish metals concentration ( $\mathrm{Fe}, \mathrm{Zn}, \mathrm{Cu}, \mathrm{Mn}, \mathrm{Cd}$ and $\mathrm{Pb}$ ) and some water quality parameters. However, metals bioavailability to Tilapia zillii is modified significantly by some water chemistry; $\mathrm{pH}$, total alkalinity and dissolved oxygen but the effect is much stronger for some metals than the others. Electric conductivity (EC) had a negative effect on accumulation of $\mathrm{Cd}$ and $\mathrm{Pb}$ in gills and liver tissue. $\mathrm{EC}$ and $\mathrm{Ca}+2$ have positive correlation on $\mathrm{Zn}$ accumulation in fish muscle tissues. The concentrations of all metals in water (except $\mathrm{Cd}$ and $\mathrm{Pb}$ ) and edible part of fish were found below the notified toxic limits. However, these elements were lower in River Nile water than in five lake's water, but the opposite was true for the fish, since these elements were higher in River Nile fish than in five lake's fish.

A survey study was conducted on some heavy metals ( $\mathrm{Pb}, \mathrm{Cd}, \mathrm{Cu}, \mathrm{Zn}$, and $\mathrm{Fe}$ ) in water, sediment, and fish samples from Ashtoum El-Gamil protected area during May 2010 to January 2011. Data obtained revealed that there were significant $(\mathrm{P} \leq 0.0001)$ differences among sampling seasons and stations as well as their interactions concerning the levels of heavy metals tested in either water, sediment, or fish collected from this protected area. The elements level took the descending order $\mathrm{Zn} \geq \mathrm{Cd} \geq \mathrm{Pb} \geq \mathrm{Fe} \geq \mathrm{Cu}$ in the water, $\mathrm{Pb} \geq \mathrm{Fe} \geq \mathrm{Cu} \geq \mathrm{Zn} \geq \mathrm{Cd}$ in the sediment, and $\mathrm{Fe}$ $\geq \mathrm{Pb} \geq \mathrm{Zn} \geq \mathrm{Cu} \geq \mathrm{Cd}$ in the fish body samples. Proximate analysis of the tested fish (mullet and tilapia) reflected also significant $\leq$ P0001) effect $\mathrm{s}$ due to sampling seasons and stations and their interactions besides fish species. Some significant correlations were calculated among heavy metals (in water, sediments, and fish) and chemical composition of the fish (Abdelhamid et al., 2013).

Concentration of Zinc (Zn) in different tissues of Oreochromis niloticus, collected from four studied sites along the River Nile, Helwan (Egypt) was determined to detect its toxic effects on one of the most common fish in the River. Oreochromis niloticus fish was found to be a good bioassay indicator for water pollution with $\mathrm{Zn}$. The results of this study clarified the importance of water chemistry in determining the bioaccumulation of the metals. The highest fluctuation from the measured water quality criteria of water samples collected from site before the industrial area, followed by that recorded for water was for those samples collected from site within the industrial area. In most cases, Zn had the least tendency to accumulate in muscles of $O$. niloticus. This means that it will be less hazardous to man if the fish muscles are the only to be eaten (Abbas and Mohamed, 2013). 
So, residues of some heavy metals in fish are affected by the presence of some industries nearby the River Nile that may negatively affect human health of the fish consumer from such contaminated water. Therefore, it is a must to convert such factories to be environmentally friends by treating its wastes before exposure to the environment.

\section{REFERENCES}

Abbas, H.H. and Mohamed, G.F. (2013). The Toxicological effects of water pollution on the Nile tilapia fish (Oreochromis niloticus) collected from four sites along the River Nile. Personal communication (National Research Center, Cairo).

Abdel-Baki, A. S.; Dkhil, M. A. and Al-Quraishy, S. (2011). Bioaccumulation of some heavy metals in tilapia fish relevant to their concentration in water and sediment of Wadi Hanifah, Saudi Arabia. African Journal of Biotechnology, 10 (13): 2541-2547.

Abdelhakeem, N.F.; Bakeer, M.N. and Soltan, M.A. (2002). Aquatic Environment for Fish Culture. Deposit No. 4774/2002.

Abdelhamid, A.M. (1994). Scientific Fundamentals for Fish Production and Management. An Arabic Textbook, Dar Al-Nashr for Egyptian Universities Alwafaa Bookshop, Cairo, I.S.B.N. 977-5526-04-1, 658 pp. (An Arabic Textbook).

Abdelhamid, A.M. (1996). Field and Laboratorial Analysis in Animal Production. Dar Annashr for Universities, Cario, Deposi No. 11318/1996, 680 pp.

Abdelhamid, A.M. (2003). Scientific Fundamentals of Fish Production and Husbandry. $2^{\text {nd }}$ Rev. Ed., Mansoura Univ. Press, Deposit No. 1424/ 2003.

Abdelhamid, A.M. (2009a). Fundamentals of Fish Production and Culture. New Universal Office, Alexandria, I.S.B.N. 977-438-052-5, 393 pp. (An Arabic Textbook).

Abdelhamid, A.M. (2009b). Modern Approach in Aquaculture. New Universal Office, Alexandria, I.S.B.N. 977-438-053-3, 393 pp. (An Arabic Textbook).

Abdelhamid, A.M. and El-Ayoty, S.A. (1989). Lead contents in feedstuffs, blood and milk of buffaloes in Dakahlia, Egypt. Buffalo Bulletin, 8: 13 - 14 \& 19 - 20.

Abdelhamid, A.M. and El-Ayoty, S.A. (1991). Effect of catfish (Clarias lazera) composition of ingestion rearing water contaminated with lead or aluminum compounds. Arch. Anim. Nutr., Berlin, 41: 757-763.

Abdelhamid, A.M. and El-Zareef, A.A.M. (1996). Further studies of the pollution status on the southern region of El-Manzalah Lake. Proc. Food Borne Contamination and Egyptian's Health Conference, 26 - 27 Nov., pp. 141 - 150.

Abdelhamid, A. M.; Abdelghaffar, A. A. and El-Kerdawy, A. A. (2000). Towards causative interpretation of the repeatedly sudden and collective death of fish in Damietta region. J. Agric. Sci. Mansoura Univ., 25: 1947-1962.

Abdelhamid, A.M.; El-Barbary, M.I. and Mabrouk, E.M.E. (2013). Some heavy metals status in Ashtoum El-Gamil protected area. Engormix.com, Aquacult. Techn. Article, 20 pp.

Abdelhamid, A. M.; El-Kerdawy, A. A.; El-Mezaein, A. A. M. and Meshref, H. A. (1997). Study on pollution in the western-north region of El-Manzalah Lake, Egypt. II. Heavy metals [Iron, zinc, lead and cadmium] in water, soil, and fish. J. Agric. Sci. Mansoura Univ., 22: 1877-1885. 
Abdelhamid, A. M.; Gawish, M. M. M. and Soryal, K. A. (2006b). Comparative study between desert cultivated and natural fisheries of mullet fish in Egypt, Iconcerning heavy metals. J. Agric. Sci. Mansoura Univ., 31: 5665 - 5680.

Abdelhamid, A.M.; Nemetallah, B.R.; Abd Allah M.A. and Mousa T.A.E. (2006a). Hemolytic activity in blood serum of Oreochromis niloticus under different types of stress. The 3rd Int. Conf. for Develop. and the Env. In the Arab world, March, 21 - 23, Assiut, pp. 153 - 169.

Abdelhamid, A.M.; Salem, M.F.I. and Tolan, A.E. (2005-a). Evaluation of linseed meal as feed ingredient in diets of growing Nile tilapia (Oreochromis niloticus). J. Agric. Res. Tanta Univ., 31(3): 385-402.

Abdelhamid, A.M.; Salem, M.F.I and Tolan, A.E. (2005-b). Utilization of black seed meal (Nigella sativa) in Nile tilapia (Oreochromis niloticus) diets. J. Agric. Res. Tanta Univ., 31(3): 403-419.

Aboul-Naga, W.M. (2000). Role of humic acids on the occurrence of metals in AbuQir Bay nearshore sediments. Bull. Nat. Inst. Oceanogr. \& Fish., A.R.E., 26: $365-383$.

AOAC, Association of Official Analytical Chemists (1995). Official methods of analysis of AOAC International, $16^{\text {th }}$ ed. AOAC International, Arlington, VA.

AOAC, Official Methods of Analysis (2006). 18 edition, Volume 1, P56, Chapter 4.

Bowden, T.J. (2008). Modulation of the immune system of fish by their environment. Fish Shellfish Immunol., 25:373-383.

Cheung, A.P.L.; Lam, T.H.J. and Chan, K.M. (2004). Regulation of tilapia metallothionein gene expression by heavy metal ions. Marine Environmental Research, 58: 389 - 394.

Daifullah, A.A.M.; Elewa, A.A., Shehata, M. B. and Abdo, M.H. (2013). Evaluation of some heavy metals in water, sediment and fish samples from River Nile (Kafr El-Zyat city), Egypt: A Treatment approach. Personal communication (email: Daifullah100@hotmail.com).

Duncan, D.B. (1955). Multiple range and multiple F-test. Biometrics, 11: 1-42.

Eid, A.E. (1995). Evaluation of fish oil, corn oil, palm oil, olive oil and beef tallow singly and in combination as supplemental dietary lipid source for fingerling Nile tilapia diets. Zagazig J. Agric. Res., 22(4): 1015 - 1022.

El-Ebiary, E.H. and Zaki, M.A. (2003). Effect of supplementing active yeast to the diets on growth performance, nutrient utilization, whole body composition and blood constituents of mono-sex tilapia (O. nilaticus). Egypt. J. Aquat. Biol. \& Fish., 7(1): 127 - 139.

ES, Egyptian standards 2360 (1993). Maximum levels for heavy metal contaminants in food. EOFS, ES: $2360-1993$.

Fan, W., Wang, W.X. and Chen, J. (2002). Geochemistry of Cd, Cr, and Zn in highly contaminated sediments and its influences on assimilation by marine bivalves. Environ. Sci. Technol., 36(23): 5164 - 5171.

Filipovic, V. and Raspor, B. (2003). Metallothionein and metal levels in cytosol of liver, kidney and brain in relation to growth parameters of Mullus surmuletus and Liza aurata from the Eastern Adriatic Sea. Water Res., 37(13): 3253 - 3262.

Galhoom, K.I.; Rizk, L.G. and El-Azzaway, M.H. (2000). Some biochemical and haematological parameter in mugil fish (Mugil cephalus) reared in Bahr ElBakar drain. Egypt. J. Agric. Res., 78(1): 1- 13.

Hovanec, T.A. (1998). What is metal toxicity? Aquarium Fish Magazine, Mar. 
Joyeux, J.C.; Filho, E.A.C. and de Jesus II, H.C. (2004). Trace metal contamination in estuarine fishes from Vitria Bay, ES, Brazil. Braz. Arch. Biol. Technol., 47(5): 1 $-11$.

Kirby, J.; Maher, W. and Harasti, D. (2001). Changes in selenium, copper, cadmium, and zinc concentrations in mullet (Mugil cephalus) from the southern basin of Lake Macquaric, Australia, in response to alteration of coal-fired power station fly ash handling procedures. Arch. Environ. Contam. Toxicol., 41(2): 171.

Mohamed, F.A.S. (2008). Bioaccumulation of selected metals and histopathological alterations in tissues of Oreochromis niloticus and Lates niloticus from Lake Nasser, Egypt. Global Veterinaria, 2 (4): 205-218.

Mzimela, H.M.; Wepener, V. and Cyrus, D.P. (2002). The sublethal effects of copper and lead on the haematology and acid-base balance of the groovy mullet, Liza dumerili. Afr. J. Aqua. Sci., 27(1): 39 - 46.

Radwan, A.M.R. (2000). Discharges on the concentrations of some heavy metals in Lake Burullos. Bull. Nat. Inst. Oceanogr. and Fish., A.R.E., 26: 355 - 364.

Rashed, M.N. and Awadallah, R.M. (1994). Cadmium and lead level in fish (Tilapia nilotica) scales as biological indicator for lake water pollution. Proc. Nat. Conf. on the River Nile, 10 - 14 Dec., Assiut Univ., pp. 265 - 277.

Rowland, I. (1981). The influence of the gut microflora on food toxicity. Proc. Nutr. Soc., 40: $67-73$.

Saeed, S.M. and Mohammed, M.A. (2012). Influence of physico-chemical characteristics of water on metals accumulation in water and Tilapia zillii inhabiting different habitats in Egypt. Journal of the Arabian Aquaculture Society, 7 (1): 29-50.

Saeed, S.M. and Shaker, I.M. (2008). Assessment of heavy metals pollution in water and sediments and their effect on Oreochromis niloticus in the northern delta lakes, Egypt. $8^{\text {th }}$ International Symposium on Tilapia in Aquaculture 2008, 475 pp.

Salem, M.F.I. (2003). Effect of cadmium, copper and lead contamination on growth performance and chemical composition of Nile tilapia (O. niloticus). J. Agric. Sci. Mansoura Univ., 28: 7209 - 7222.

SAS (2001). SAS/STAT Guide for personal computer. SAS Inst. Cary, N.C.

Siam, E.E. (2001). Evaluation of heavy metals concentration in fish rom Alexandria Coast, Egypt. file: //D:IDR_MAHAlvol_4_2.htm.

Staniskiene, B.; Palavinskas, R. and Boes, C. (2005). Study of concentration of heavy metals in fish. File: //D; \DR-MAHAlstaniskiene_en.htm.

Wedemeyer, B.A. (1997). Effects rearing conditions on the health and physiological quality of fish in intensive culture. In: Fish Stress and Health in Aquaculture. G.K. Iwama , A .D. Pickering, J.P. Sumpter and C.B. Schbridge, Univ. Press.

WRC (2005). Albany Waterways Resource Book: Water quality, Water quality Parameters. //H: Ifish $\backslash W R C \% 20$ Albany \% 20 Waterways \% 20 Resource \% 20 Book \% 20 Water \% 20.

Xie, L. and Klerks, P.L. (2004). Changes in cadmium accumulation as a mechanism for cadmium resistance in the least killifish Heteradria formosa. Aquat. Toxicol., 66 (1): $73-81$.

Yilmaz, A.B. (2005). Comparison of heavy metal levels of grey mullet (Mugil cephalus L.) and sea bream (Sparus aurota L.) caught in Iskenderun Bay (Turkey). Turk. J. Vet. Anim. Sci., 29: 257 - 262.

Yokokawa, T. (2000). Water Quality for Coastal Aquaculture. Training Manual on Marine Finfish Net cage Culture in Singapore. 
Zyadah, M.A. (1997). A study on levels of some heavy metals in River Nile estuary Damietta branch, Egypt. J. Egypt. Ger. Soc. Zool., 23(A): 149 - 160.

\section{ARABIC SUMMERY}

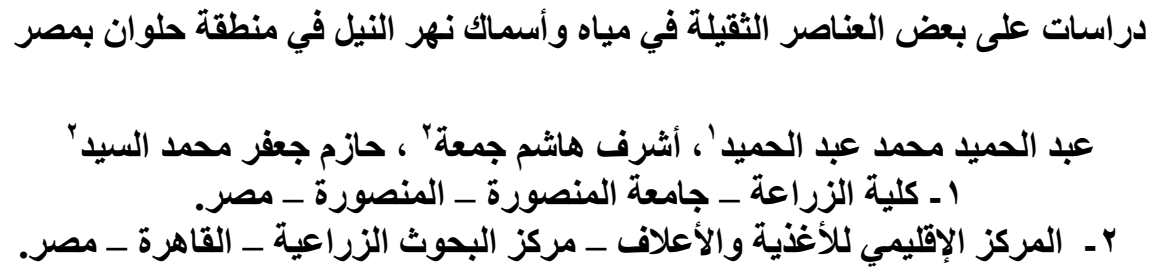

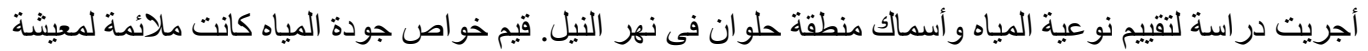

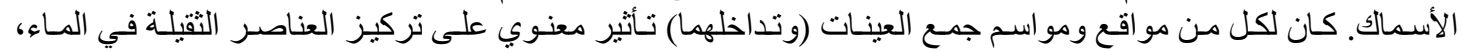

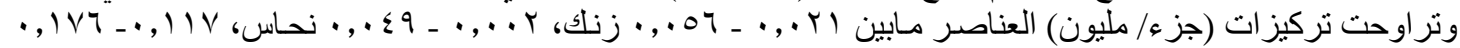

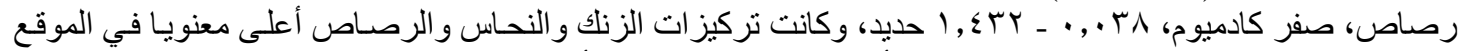

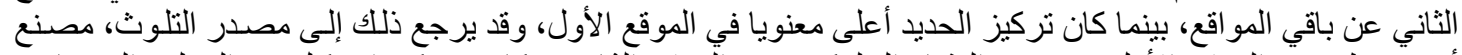

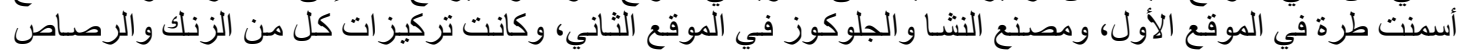

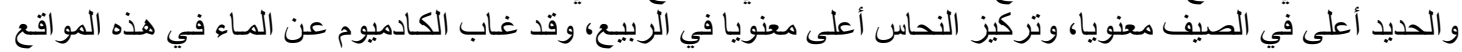

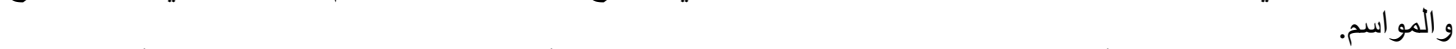

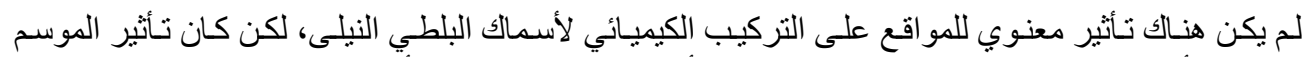

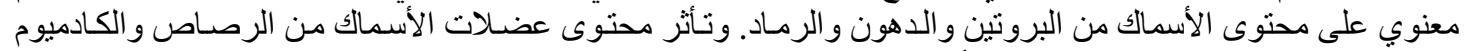

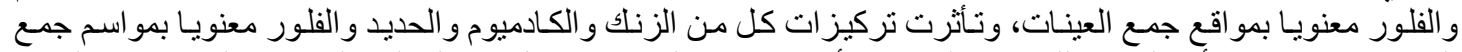

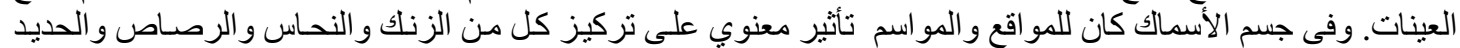

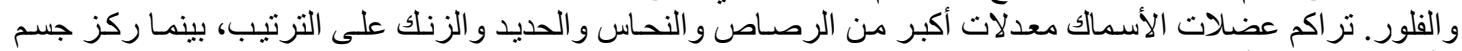

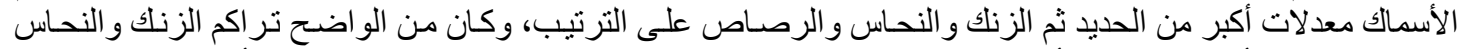

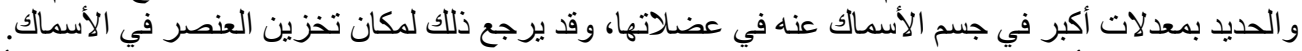

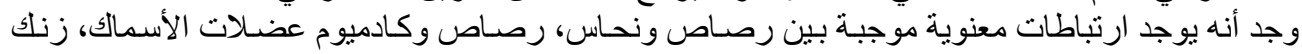

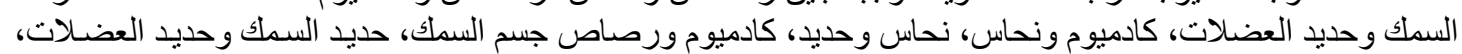

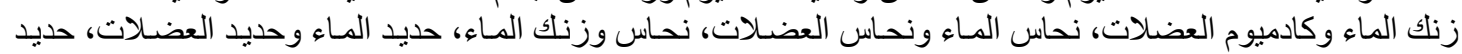

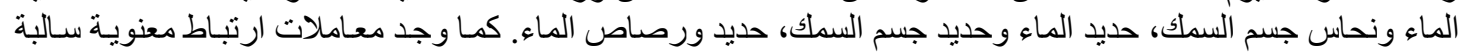

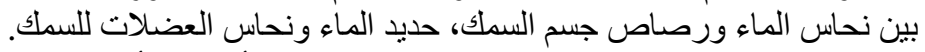

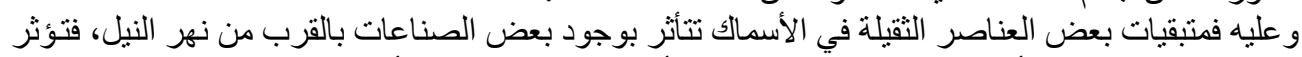

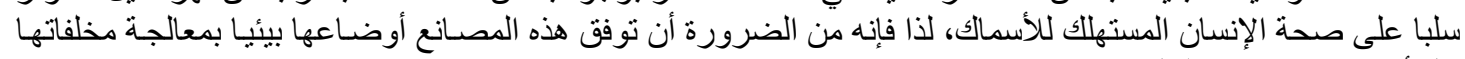

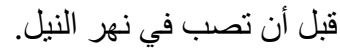

